\title{
Celebrating 25 years of advances in micropalaeontology: a review
}

\author{
F. JOHN GREGORY (EDITOR) ${ }^{1}$, HOWARD A. ARMSTRONG ${ }^{2}$, IAN BOOMER ${ }^{3}$, RAINER GERSONDE ${ }^{4}$, \\ IAN HARDING ${ }^{5}$, JENS O. HERRLE ${ }^{6}$, DAVID LAZARUS ${ }^{7}$, DANIELA N. SCHMIDT ${ }^{8}$, JOACHIM SCHOENFELD ${ }^{9} \&$ \\ JEREMY R. YOUNG ${ }^{10}$ \\ ${ }^{1}$ PetroStrat Ltd, 33 Royston Road, St Albans, Herts AL1 5NF \& Palaeontology Department, NHM, Cromwell Road, London SW7 5BD, UK \\ (e-mail: john@petrostrat.com) \\ ${ }^{2}$ Department of Earth Science, Durham University, South Road, Durham DH1 3LE, UK (e-mail: h.a.armstrong@durham.ac.uk) \\ ${ }^{3}$ Stable Isotope \& Luminescence Laboratory (SILLA) School of Geography, Earth \& Environmental Sciences University of Birmingham, \\ Edgbaston B15 2TT, UK (e-mail: i.boomer@bham.ac.uk) \\ ${ }^{4}$ Alfred-Wegener-Institute for Polar \& Marine Research, Postbox 120161, Bremerhaven, Germany (e-mail: rgersonde@awi-bremerhaven.de) \\ ${ }^{5}$ School of Ocean \& Earth Science, NOC, University of Southampton, European Way, Southampton SO14 3ZH, UK \\ (e-mail: ich@soc.soton.ac.uk) \\ ${ }^{6}$ Department of Earth \& Atmospheric Sciences, University of Alberta, 1-26 Earth Sciences Building, Edmonton, Alberta T6G 2E3, Canada \\ (e-mail: herrle@ualberta.ca) \\ ${ }^{7}$ Museum für Naturkunde, 10115 Berlin, Germany (e-mail: david.lazarus@rz.hu-berlin.de) \\ ${ }^{8}$ Department of Earth Sciences, University of Bristol, Wills Memorial Building, Bristol BS8 1RJ, UK (e-mail: d.schmidt@bristol.ac.uk) \\ ${ }^{9}$ Leibniz-Institute of Marine Sciences, IFM-GEOMAR, Dienstgebaeude Ostufer, Wischhofstraat 1-3, D-24148 Kiel, Germany \\ (e-mail: jschoenfeld@geomar.de) \\ ${ }^{10}$ Palaeontology Department, The Natural History Museum, Cromwell Road, London SW7 5BD, UK (e-mail: j.young@nhm.ac.uk)
}

\section{INTRODUCTION (F. JOHN GREGORY)}

To commemorate the publication of the $25^{\text {th }}$ Volume of the Journal of Micropalaeontology, the first issue of which came out in 1982, this celebratory review article was commissioned. Officers of each TMS Group (Ostracod, Foraminifera, Palynology, Nannofossil, Microvertebrate and Silicofossil) were requested to reflect over the last 25 years and assess the major advances and innovations in each of their disciplines. It is obvious from the presentations that all Groups report that research has moved on from the basic, but essential descriptive phase, i.e. taxonomy and establishing biostratigraphies, to the utilization of new technologies and application to issues of the day such as climate change and global warming. However, we must not lose sight of the fact that the foundation of micropalaeontology is observation and the building block for all these new and exciting innovations and developments is still good taxonomy. Briefly, the most obvious conclusion that can be drawn from this review is that micropalaeontology as a science is in relatively good health, but we have to ensure that the reported advancements will sustain and progress our discipline. There is one issue that has not really been highlighted in these contributions - we need to make sure that there are enough people being trained in micropalaeontology to maintain development. The last 25 years has seen a dramatic decrease in the number of post-graduate MSc courses in micropalaeontology. For example, in the UK, in the 1980s and early 1990s there were five specific MSc courses to choose from (Hull, Southampton, Sheffield, Aberystwyth and UCL) now there is just one left, run jointly by UCL and the Natural History Museum, in London. This decrease occurred for a variety of reasons but was related initially to fluctuations in oil price, leading to a lack of stability and confidence in the oil industry which used to attract many postgraduates. Fortunately, there has been a recent trend to try and bolster student numbers with the introduction of multidisciplinary postgraduate courses which include an element of micropalaeontology, and there are more students entering the subject through PhD programmes than in the past.
I wonder what my successor as Editor will be able to report in 25 , or even 50 years? The most significant factor then, is that oil - which has provided a good number of us with a career or funding to do academic research - will be entering its final phase. We will all need to be on the hunt for new horizons and this has already started, especially in the last 5-10 years, as illustrated in the following reports. My bet is that we will look back and see major advances based on further enhancements in biological and imaging technologies and an increase in integrated multi-disciplinary studies, with the inclusion of two or more microfossil groups (something that I feel has not really happened yet). Here's to the future.

\section{Acknowledgement}

FJG would like to thank Mark Williams (Leicester) and David Siveter (Leicester) for providing reviews of this article and also to members of the various TMS Groups who offered support and additional comments to several of the Group contributions.

\section{OSTRACODS (IAN BOOMER, WITH CONTRIBUTIONS FROM THE OSTRACOD GROUP, TMS)}

\section{Introduction: from time markers to environmental indices}

The past 25 years have seen a number of advances in our understanding of the Ostracoda and their application to the earth and life sciences, with a marked shift in emphasis from their use in biostratigraphy to indicators of environmental change both faunally and geochemically. The first Stratigraphical Atlas published by The Micropalaeontology Society (Bate \& Robinson, 1978), was the Ostracoda (the second edition of which will be published in 2007). Their application to the study of environmental change has been largely driven by technological advances and an increasing focus across the earth and environmental sciences on the global climate system and quantification of the rate and magnitude of past climate events. These changes have been mirrored in the decreasing call from oil 
companies for ostracod workers but a continued presence within universities and research institutes, particularly those investigating climate change.

The fossil ostracod record continues to be a major focus for research and has led to some of the important advances, particularly in evolutionary biology, outlined below. In recent years a number of research groups, particularly in Europe and Japan, have concentrated on the ostracods as living organisms, leading to a greater understanding of the interaction between species and environment. Advances in the study of fresh-water faunas led to the establishment of regional ostracod databases, i.e. NODE, Non-marine Ostracod Distribution in Europe (Horne et al., 1998) and NANODE, North American Non-marine Ostracod Database (Forester et al., 2005).

The last 25 years has also seen advances in our knowledge of one of the most fundamental aspects of ostracod biology, the structure, composition and calcification process of the ostracod carapace (e.g. Keyser \& Walter, 2004).

\section{When is an ostracod not an ostracod? Cambrian ostracod record questioned?}

Twenty-five years ago the fossil ostracod record extended from the Early Cambrian to Recent. Since then, our knowledge of fossil ostracods and their allies has been advanced significantly by the discovery and investigation of a number of Palaeozoic Lagerstätten. The lower Cambrian Chengjiang Lagerstätte has yielded the only known bradoriid with soft parts (Hou et al., 1996), while the upper Cambrian 'Orsten' of the Baltic (e.g. Maas et al., 2003) and the lower Cambrian of England (Siveter et al., 2001) have yielded phosphatocopids with soft parts. These finds demonstrate that typical bradoriids lie outside the Crustacea s.s. and that phosphatocopids are the sister group to the Eucrustacea, thus debunking the Cambrian ostracod record. Some Cambrian bradoriids may yet prove to be true ostracods; however, without soft parts it is impossible to be certain. The earliest confirmed ostracods are now Early Ordovician.

\section{A long history of sex - or celibacy}

Perhaps most remarkable amongst these studies is the discovery of three-dimensional preservation of soft parts from the Silurian of the Welsh Borderlands. Using computer imaging, a Silurian myodocope with soft-part anatomy (Siveter et al., 2003) has pushed back the earliest described evidence for ostracod soft-part anatomy by nearly 200 million years and provided unequivocal evidence for the occurrence of Ostracoda in the Palaeozoic. It also gave the earliest unequivocal testimony for male gender in any group of animals.

Non-marine darwinulid ostracods have achieved fame as an 'ancient asexual' lineage, confounding evolutionary theory by apparently surviving without sex since the beginning of the Mesozoic (Martens et al., 2003). However, this has recently been called into question, although not totally disproved, by the discovery of elusive darwinulid males (Smith et al., 2006).

\section{The origin of pelagic ostracods: an ecological shift in the Silurian}

Another important discovery from the Palaeozoic saw the development of a model that explained the timing and nature of the appearance of pelagic ostracods during the Silurian. Early
Silurian myodocope ostracods were benthic, living on welloxygenated marine shelves. Myodocope ostracods appear to have undergone an ecological shift by the Late Silurian, an event that provides the best evidence for the earliest occurrence of pelagic ostracods in the fossil record (Siveter, 1984; Siveter et al., 1987; 1991).

\section{The rise of the machines: quantifying past environmental changes}

Technological advances in analytical equipment have, in part, led to new applications for ostracods. The ability to analyse the isotopic and chemical composition of individual (or a very few) shells has provided the ability to quantitatively reconstruct past water temperature, solute and isotopic composition. This has brought ostracods to the fore in a number of fields, including palaeoclimatology, palaeoceanography and palaeolimnology.

Chivas et al. (1983, 1986a, b) did much to develop the ostracod shell-chemistry technique in non-marine systems, focusing on local and regional changes in hydrology, although debate continues as to the interpretation that may be drawn from such data. Von Grafenstein et al. (1999) demonstrated that the stable isotope geochemistry of benthic ostracods in southern European lakes could be correlated in detail with late Quaternary climate records from the Greenland ice-cores (see also reviews of applications by De Deckker (2002) and von Grafenstein (2002)).

Geochemical approaches have also been applied to the deepsea record (e.g. Dwyer et al., 1995, 2002; Cronin \& Raymo, 1997), building upon the fundamental Deep Sea Drilling Project (DSDP) and Ocean Drilling Program (ODP) taxonomic work of Benson in the USA and the Aberystwyth School under the direction of Robin Whatley.

\section{Genetics and taxonomy}

The 'genetic revolution' in the biosciences has led to significant technical advances that have also benefited ostracod research. The development of DNA replication technologies has allowed the relatively small amount of DNA from ostracods to be analysed, advancing understanding of ostracod evolutionary biology.

Ostracod research is still underpinned by knowledge of taxonomy, ecology and geological processes. Although the number of scientists undertaking purely taxonomic work dwindles, that expertise continues to be fundamental to the applications outlined above and remains an important skill of all ostracodologists. Most workers today are indebted to the invaluable work of Kempf and his group (University of Köln), who continue to maintain an ostracod publication database, recording descriptions of new taxa in the 'Kempf Database on Ostracoda' (e.g. Kempf, 1996, 1997).

Despite the disappearance of the only serial publication dedicated to the Ostracoda, A Stereo-Atlas of Ostracod Shells, which ceased publication in 1998 after 25 years and the description of 720 fossil and living taxa, ostracod research is thriving today throughout the world.

\section{FORAMINIFERA (DANIELA SCHMIDT \& JOACHIM SCHOENFELD)}

\section{Introduction}

Looking back over 25 years of foraminiferal research from a personal point of view is a daunting task. How do we 
quantify the importance of research? In particular since today's research of encompassing ecosystem analysis and multi-proxy approaches make it difficult to 'assign' it to foraminiferal research. In contrast, in the 1970s research focused more clearly on the organisms, with emphasis on the ecology and biology of planktonic (Bé, 1977) and benthic (Murray, 1973) foraminifers. Actualistic understanding of foraminiferal ecology provided the justification for use of their shells for stable isotope and trace metal analyses and changed the field of foraminiferal research. However, in the early 1980s, many researchers were convinced that the distribution of foraminifera was driven by single, physical or chemical parameters - for example, water depth, temperature or salinity. The mid- and late 1980s saw a profound widening of this scope due to many new insights and evidence that multiple environmental parameters and the physiology of foraminifers account and interact in a web of environmental forcings.

This new understanding of ecology and rapid innovation of computer technology resulted in dramatic changes for foraminiferal micropalaeontology: for example, the use of planktonic foraminiferal assemblages combined with multivariate statistics to reconstruct past sea-surface temperatures (CLIMAP Project Members, 1981). This gave way to the rise of palaeoceanography, the invention of astronomical age models, tracking ancient water mass distributions and the first numerical models (Imbrie et al., 1984).

\section{Stratigraphy}

Since the early 1980s, foraminiferal biozonations have been available for most stages (e.g. various planktonic zonations contained within Bolli et al. (1985) for the Cretaceous to Recent). However, these schemes have been refined and revised using astronomical time-scales, which provide the means to date sediments with unprecedented accuracy, particularly for the Cenozoic to Recent (e.g. Shackleton et al., 1990).

\section{Refinement in palaeoecology}

We have learned that the distribution of benthic foraminifera in the sea bed is structured into different microhabitats (Corliss, 1985) and that foraminifera respond rapidly to phytodetritus deposition, which turns the deep sea into one of the most seasonal environments on Earth (Gooday \& Lambshead, 1989). The observation of salt-marsh foraminifera in tidal estuaries (Scott \& Medioli, 1980) introduced a centimetre-precise sea-level gauge, applicable as far back in time as the Late Carboniferous. Studies of shape (Malmgren et al., 1983) produced classic papers suggesting new microevolutionary models. The late 1980s and 1990s saw a merging of these new observations with statistics. Statistical methods were used to define species groups with similar ecological preferences and to link them to steering environmental parameters (Lutze \& Coulbourn, 1984). As statistical results were often ambiguous, more detailed observations were necessary to make the next step forward. Food and oxygen were considered to be the most important environmental factors for foraminiferal distributions. Hence, it was attempted to use their abundance and species composition for estimates of primary production, oxygen content of bottom waters and the flux of particulate organic matter to the sea floor (Mix, 1989; Herguera \& Berger, 1991; Kaiho, 1994). However, it was difficult to discern the interfering influences of food flux and oxygen availability in pore waters below the sediment surface (e.g. Jorissen, 1999).

\section{New technologies: impact}

The rise of new biotechnology in the 1990s facilitated a sensible revision of the Kingdom Protozoa using molecular genetics (Cavalier Smith, 1993). The emerging field of foraminiferal molecular genetics (Darling et al., 2000, 2004; de Vargas et al., 2001) led to the discovery of cryptic species (Huber et al., 1997), which will significantly improve our understanding of foraminiferal ecology and evolution. In recent years, stable isotopes and trace metals, in particular $\mathrm{Mg} / \mathrm{Ca}$ for temperature estimates, have been the focus of current research and further the use of foraminifera as palaeoceanographic proxy carriers (Vincent et al., 1981; Delaney \& Boyle, 1987; Pearson \& Palmer, 2000).

\section{Final thoughts}

Both, genetics and geochemistry heightened the demand for a sound and timely concept of foraminiferal taxonomy. Benchmark textbooks have aged (Morkhoven et al., 1986; Loeblich \& Tappan, 1987; Hemleben et al., 1989; Jones, 1994) and new research is required because, ultimately, every conclusion is just as good as the taxonomy on which it is based. As a final thought, readers may be interested in the highest cited paper using foraminifers during the last 25 years. Some may think it unimportant, but for those of you who do consider it important - the winning paper, with 642 citations, is by Nick Shackleton and colleagues (1990) on the 'Astronomical calibration of the Lower Pleistocene Timescale based on ODP Site 677'. They dissolved foraminifers to analyse oxygen isotopes, resulting in the most accurate time-scale. Who would have thought about this in the 1940s when people started to date marine sediments with foraminifers?

\section{PALYNOLOGY (IAN HARDING, WITH CONTRIBUTIONS FROM THE PALYNOLOGY GROUP; TMS)}

\section{Introduction}

The last 25 years has witnessed the 'coming of age' of palynology: a dramatic and exponential maturing of the discipline, progressing from straightforward descriptions of new taxa and the development of biostratigraphic zonations to its current role as a fully integrated tool operating alongside complementary areas of research in the quest to understand complex geological problems, both in an academic and industrial context. The literature cited in this short review will, by necessity, be selective and examines a small spectrum of thematic areas of palynological research. However, an attempt has been made to include references from the various fields of dinoflagellate, spore, pollen, acritarch, chitinozoan and palynofacies studies, in addition to balancing academic and industrial facets of the subject.

The striking palynological advances that have been made in the past quarter of a century would have been impossible without such seminal works as those by Tappan (1980) and Traverse (1988). Both are landmark syntheses of information concerning a plethora of palynological groups, while the three-volume Jansonius \& McGregor (1996) is still the most 
comprehensive set of literature yet assembled that covers all aspects of palaeopalynology. The major tomes in the field of palynofacies analysis have been the publications of Traverse (1994) and, perhaps most notably, Tyson (1995). The latter is still a standard text and widely cited, together with Batten's (1996a, b) contributions. Jones \& Rowe (1999) provided an exhaustive compilation of techniques related to fossil plants and sporomorphs.

The aquatic palynomorphs have perhaps seen the most significant gains in understanding, based on such works as the Big Blue Book (Evitt, 1985), perhaps one of the most significant tomes ever written on the dinoflagellates. This was a progenitor of the first widely accepted classification of modern and fossil dinoflagellates, by Fensome et al. (1993), itself now a classic work. Acritarchs have been reviewed by Strother (1996) and chitinozoa by Paris \& Nõlvak (1999). Other notable works have drawn together biostratigraphies for the various aquatic palynomorphs, in the forms of Williams \& Bujak (1985) and Powell (1992) for dinoflagellates (the latter published under the auspices of this society), Downie (1984) for acritarchs and Verniers et al. (1995) and Paris et al. (2000) for chitinozoa.

Our understanding of several groups of organic-walled fossil microplankton would not be as advanced as it is today without the expertise of neontologists: collected works by Spector (1984) and Taylor (1987) provided thematic papers on dinoflagellates, while the pioneering work of Harland (1983), documenting the distribution of dinoflagellate cysts in modern oceans, has been built upon by such works those of Rochon et al. (1999) and Marret \& Zonneveld (2003).

Eye of newt, toe of frog: demystifying palynomorph chemistry Progress has been made towards understanding the structure, function, chemical diversity and diagenetic modification of palynomorph walls, furthered by such works as de Leeuw \& Largeau (1993) and van Bergen et al. (2004). The important review by Versteegh \& Blokker (2004) brought together compositional analyses of extant and fossil microalgae, illustrating biosynthetic pathways for the production of resistant biomacromolecules. Hemsley and co-workers have discussed selfassembly as an important process in wall formation (e.g. Gabarayeva \& Hemsley, 2006, and references therein), whereas works such as that by Marshall et al. (2005, on Proterozoic acritarchs) demonstrate the role new analytical techniques can play in analysing palynomorph composition.

Several degradational and preservational pathways for organic matter in the fossil record have been proposed (e.g. Tissot \& Welte, 1984; Sinninghe Damsté \& de Leeuw, 1990) and a greater appreciation of these processes is required to assess fully the extent to which the geomacromolecules represent the original biomacromolecules, as palynomorph cell walls are modified readily by elevated temperature and pressure conditions (e.g. Arouri et al., 2000) and oxygen concentrations (Versteegh \& Zonneveld, 2002).

\section{Taxonomy, morphological problems and evolution: the gene} genie

There has been tremendous clarification of the taxonomy and systematics of most palynological groupings, assisted by such encyclopaedic data compilations as the Lentin \& Williams
(1973) dinoflagellate index (culminating in Fensome \& Williams, 2004) and Fensome et al.'s (1990) publication for the acritarchs. Chitinozoan workers have agreement on suprageneric classification (Paris et al., 1999), but work remains to be done at a specific level. Digital databases and online resources now have a vital role to play in the global dissemination of such information (e.g. Achab et al., 2000).

Laboratory cultures have proven to be of huge importance in clarifying planktonic life cycles and phylogenetic relationships (e.g. Kokinos \& Anderson, 1995; Ellegaard et al., 2003). They will increase in importance, given genomic investigations showing that unicellular organisms can demonstrate cryptic speciation, serving to further emphasize the precision with which morphotaxa must be circumscribed. New biogeochemical genetic and cladistic techniques have had a major impact on dinoflagellate phylogenetic studies (e.g. Fensome et al., 1996; Moldowan \& Talyzina, 1998; Saldarriaga et al., 2004). However, the discovery of extra-thecal cysts of the dinoflagellate Palaeoperidinium (Evitt et al., 1998) and the 'dinocasts' of Versteegh et al. (2004) illustrate that the fossil record will continue to divulge oddities.

The evolution and phylogenies of the terrestrial plants have also been active areas for palynological contributions, notably for the angiosperms (e.g. Walker \& Walker, 1984; Cornet, 1989; Hughes, 1994; Brenner, 1996; Hochuli \& Feist-Burkhardt, 2004), while in situ studies of spores and pollen (e.g. Balme, 1995) have played a major role in understanding the early evolution of land plants (e.g. Wellman et al., 2003) and thinsection studies (e.g. Batten \& Dutta, 1997) have been useful for determining botanical relationships. This work helps to inform genetically and morphologically based cladistic analyses (e.g. Qiu \& Lee, 2000), in combination with meso- and macro-fossil data (e.g. Friis et al., 2006).

\section{From qualitative to quantitative, isolation to integration}

The emphasis placed on much palynological research has shifted from the descriptive and qualitative to more rigorous quantitative approaches, employing statistical and computational methodologies. Quantitative techniques applied in palynological contexts include a variety of multivariate statistical procedures (such as cluster analysis) and ordination methods, such as principal component analysis (PCA), correspondence analysis (CA) and detrended correspondence analysis (DCA) (e.g. Dale $\&$ Dale, 2002). In addition, sporomorph workers have developed methods, such as squared-chord distance dissimilarity coefficient (SCD), average pairwise dissimilarity and total variance, nearest living relative (NLR) and coexistence analyses (CoA) (e.g. Overpeck et al., 1992; Mosbrugger \& Utescher, 1997; Lupia, 1999; Liang et al., 2003, Poole et al., 2005). Although a common methodology employed by foraminiferal workers, transfer functions have not received the same attention from palynologists, excepting such work as that by Mudie (1992). Shaw's graphic correlation method has been utilized in the erection of biostratigraphies (Edwards, 1989; Eldrett et al., 2004), as has automated correlation (D'Iorio, 1986).

Palynological investigations are now firmly embedded in multidisciplinary geological studies, from those of academic interest to those on an industrial and societal scale, such as global climate change. The last 25 years have seen the 
hydrocarbon exploration industry continue to provide major impetus to palynology, especially in the context of sea-level change and the development of sequence stratigraphy - with papers by Parry et al. (1981), Davies et al. (1991), Gorin \& Steffen (1991), collected papers in Katz \& Pratt (1993), Partington et al. (1993), Hart et al. (1994), Achab et al. (1997) and Winchester-Seeto et al. (2000) providing some notable contributions in the areas of palynofacies, dinoflagellates, chitinozoa and sporomorphs. Techniques for the determination of thermal maturity have also 'matured' over the past 25 years, with quantified studies examining spore colour (Marshall, 1991; Yule et al., 2000), acritarch fluorescence (Obermajer et al., 1999) and chitinozoan reflectance (e.g. Tricker et al., 1992).

However, it is perhaps in the fields of palaeoecology, palaeogeography and climate change that palynology has made, and will continue to make, significant contributions to integrated research, especially concerning notable 'boundary events' such as the Cretaceous/Tertiary boundary (e.g. Tschudy et al., 1984; Sweet, 1994; Nicholls, 2003) and the Paleocene/Eocene boundary (Wing et al., 2005; Crouch \& Brinkhuis, 2005; Sluijs et al., 2006). By combining palynological research with sedimentology, stable isotope analysis, geochemistry, Milankovitch cyclicity and climate modelling (e.g. Versteegh, 1994; Pearson et al., 2004), recent studies have demonstrated the potential of palynology. A variety of groups across a spectrum of depositional environments throughout the geological column have been examined (e.g. Huber et al., 2004; Mullins et al., 2004; Grice et al., 2005; Brinkhuis et al., 2006, Stricanne et al., 2006) - this is likely to be one of the main directions of palynological research over the next 25 years.

\section{NANNOFOSSILS (JEREMY R. YOUNG \& JENS O. HERRLE)}

\section{Taxonomy and biostratigraphy}

Twenty-five years ago, the field was coming to the end of an intensive period of primary descriptive work, during which most of the obvious calcareous nannoplankton species had been described and the basic zonations we still use had been developed - at least for the Late Cretaceous and Cenozoic. Since then the most obvious development has been broadening of the scope of nannoplankton research beyond taxonomy and biostratigraphy, but there have also been major developments in these areas. The Jurassic and Early Cretaceous nannofloras have been monographed lovingly (e.g. Bown, 1987), Mesozoic and Cenozoic zonations have been calibrated against magnetostratigraphy (e.g. Monechi \& Thierstein, 1985; Bralower et al., 1995) and, more recently, cyclostratigraphy and finer resolution zonations have been developed (e.g. Varol, 1989; Burnett, 1998; Raffi et al., in press) and, perhaps most importantly, the data have been synthesized accessibly. There are two obvious benchmark publications: first, the Bolli et al. (1985) 'yellow book', Plankton Stratigraphy, which includes a 250-page synthesis of nannofossil taxonomy by Katharina Perch-Nielsen; second, the Bown (1998) 'black book' Calcareous Nannofossil Biostratigraphy, a Special Publication of our society. The work has paid dividends, with nannofossils becoming one of the most widely used and reliable sources of biostratigraphic data. The good quality taxonomy, based largely on meaningful biomineralization-based characters
(Young et al., 1992) and, more recently, on morphometry (Bollmann, 1997), has been vindicated by molecular genetic studies (e.g. Saez et al., 2004).

\section{Coccolithophore biology and ecology}

In the early 1980s coccolithophore biology and ecology was as woefully a neglected field as that of any microfossil group and, as with other groups, this led palaeontologists to undertake new research on their taxonomy, biogeography and ecology, with outstanding PhD studies (for example, by Mara Cortés, Ali Haidar, Ric Jordan and Annelies Kleijne). For coccolithophores, however, this general pattern was reinforced by a number of special factors. First, coccolithophore blooms provided some of the most dramatic features seen in satellite images of the oceans (Holligan et al., 1983). Secondly, coccolithophores were adopted as model organisms for biomineralization study, especially by Peter Westbroek's group. Thirdly, coccolithophore-derived alkenones proved invaluable biomarkers and palaeothermometers (Brassell et al., 1986). Fourthly, development of sediment traps and interest in the carbon cycle stimulated extensive research on coccolith fluxes (Ziveri et al., 1995). All these factors would certainly have led to widespread research on coccolithophores, but the field was stimulated immensely by Peter Westbroek's dream to integrate everything through multi-disciplinary research on Emiliania huxleyi to make it the Escherichia coli of the ocean, i.e. a model organism to understand marine biogeochemistry (Westbroek et al., 1993). This dream led to a succession of interdisciplinary workshops hosted by Jan van Hinte in the Chateau de Blagnac. These, in turn, spawned a series of multi-national projects and have indeed made E. huxleyi one of the most widely studied marine protists (and its genome is close to being sequenced). More broadly, our knowledge of coccolithophore life cycles, ecology, biomineralization biochemistry, molecular biology and biodiversity has changed beyond recognition. Key syntheses of this work include Coccolithophores (Winter \& Siesser, 1994), Coccolithophores - from molecular processes to global impact (Thierstein \& Young, 2004) and the pioneering work on $E$. huxleyi of Eystein Paasche, John Green and William Balch, summarized excellently by Paasche (2002).

\section{Coccolithophore palaeobiology, palaeoceanography and global change}

Of course, in parallel with this biological work, the agenda of micropalaeontological research was shifting to palaeoceanography and global change, and this has certainly been reflected in nannofossil research. An early highlight was extensive research on the mid-Cretaceous Oceanic Anoxic Events (e.g. Bralower et al., 1994; Erba, 1994), the K/T boundary (e.g. Pospichal, 1994), followed more recently by much work on the PETM (e.g. Gibbs et al., 2006). Broader palaeoceanographic studies have been hampered by difficulties in developing reliable quantitative palaeoproxies, reflecting the rapid evolution of coccolithophores and the tendency for assemblages to be dominated by a narrow range of eutrophic/mesotrophic species. However, for the Mesozoic, one of the most important and fundamental ecological and palaeoceanographic studies goes back to Roth \& Krumbach (1986), introducing for the first time a preliminary toolbox for semi-quantitative nannoplankton-based proxies for 
reconstructing Mesozoic palaeoceanographic changes. Prime examples for using coccolithophores as quantitative proxies in the field of palaeoceanography are the development of Florisphaera profunda as an indicator of water column stratification and oligotrophy (e.g. Molfino \& Mcintyre, 1990; Beaufort et al., 1997) and the Gephyrocapsa-palaeothermometer (Bollmann et al., 2002). In general, however, coccolithophores have probably not yet come near to realizing their potential in palaeoceanography. This seems to be changing fast as the results of biological research are applied to nannofossil research, resulting in new biotic proxies based on more refined species concepts (e.g. Bollmann, 1997). Of equal importance are new geochemical proxies based on the refined understanding of coccolith chemistry (Dudley et al., 1986) and on new techniques for separating nannofossil assemblages into narrow size fractions, as introduced by Paull \& Thierstein (1987) and recently improved by Minoletti et al. (2005), enabling high quality geochemical data to be extracted from the nannofossil record.

\section{Final thoughts}

It is always dangerous to attempt predictions, but our suspicion is that two emerging trends will lead nannofossil research over the next few years. First, automated methods will allow rapid generation of data from normally preserved assemblages and methods are in progress (Beaufort \& Dollfus, 2004; Bollmann et al., 2004). Secondly, detailed analysis of exceptionally preserved assemblages will enable us to provide a much more meaningful picture of the phylogeny, palaeobiodiversity and evolutionary development of coccolithophores in relation to long-term global environmental change.

\section{MICROVERTEBRATES (HOWARD A. ARMSTRONG)}

\section{Introduction}

The Microvertebrate Group includes researchers interested in the Palaeozoic fossil record of vertebrates as revealed by their tiny scales, teeth and bone fragments extracted from rock samples. Such 'micro-remains' are derived from a variety of animals and have important applications in biostratigraphy, palaeoecology, palaeobiogeography, anatomy and phylogeny. The thelodonts and conodonts, extinct jawless vertebrates, are the most widely studied 'micro-vertebrates'. Commonality is also found in that the fossil record of both of these groups is dominated by collections of discrete skeletal elements and our understanding of their palaeobiology has undergone revolutionary change in the last 25 years.

Conventionally thelodonts have been perceived as dorsoventrally compressed fish-like animals, with unsupported pectoral flaps, dorsal and anal fins, and a hypocercal tail (Turner, 1991). However, whilst this body plan may apply to most thelodonts, the recently discovered Furcacaudiformes (Wilson \& Caldwell, 1998) are characterized by a deep, hump-backed and laterally compressed body, approximately symmetrical tail and lack the anal fins of dorso-ventrally compressed thelodonts (Wilson \& Caldwell, 1993, 1998; Caldwell \& Wilson, 1995). Thelodonts characteristically possess a dermal skeleton composed of thousands of microscopic scales that are commonly dispersed after death. Recent description of the full anatomy of Turinia pageri (Powrie), the holotype, has resolved the mor- phology, anatomy and phylogenetic relationships of at least one of the groups, the thelodonts. Phylogenetic analysis resolves $T$. pagei (and likely all thelodonts) and the Galeaspida as sistertaxa, comprising a sister group to the Osteostraci plus jawed vertebrates (Donoghue \& Smith, 2001).

Since the 1930s conodonts have become the premier microfossils for dating Palaeozoic shallow-marine carbonates and they have been used widely in palaeoecological and biogeographical studies. Conodonts are now the microfossil group of choice for biostratigraphical work of Late Cambrian to Triassic age. Graphical correlation has been used to constrain taxon ranges through much of the Ordovician and Silurian (Kleffner, 1995; Sweet, 1995), parts of the Devonian (Klapper, 1989) and the lower part of the Triassic (Sweet, 1989) and composite standards compiled graphically have been used in the analysis of mass extinction (Armstrong, 1995, 1999). Work progresses on developing a composite standard for the rest of the Palaeozoic and Triassic. Attempts to date conodonts using radiometric and other methods have proved successful but give large error bars (Sachs et al., 1980; Ueki \& Sano, 2001). Conodont colour alteration (CAI) has been extended to indicate a range of temperatures from $25^{\circ} \mathrm{C}$ to $600^{\circ} \mathrm{C}$ and has been applied widely in the interpretation of basin histories, regional metamorphic studies and in the search for hydrocarbons and minerals.

The study of conodonts was advanced greatly in 1983 by the discovery of complete conodont animals in the Carboniferous Granton Shrimp Bed near Edinburgh (Briggs et al., 1983). The excellent preservation of the material has provided detailed information on the anatomy of conodont animals, including sclerotic eye cartilages, notochord and chevron muscle blocks that have indicated a chordate affinity for the group (Aldridge et al., 1986, 1993). A further animal of lower Silurian age (Mikulic et al., 1985; Smith et al., 1987) and giant conodont animals of Upper Ordovician age (Aldridge \& Theron, 1993; Gabbott et al., 1995) have since been discovered. The Ordovician animals differ from the Granton animals in the architecture of the apparatus, the size of the elements and the overall size of the animal, which could have reached $1 \mathrm{~m}$ in length. A single specimen preserves extrinsic eye musculature and the trunk muscles that show details of rod-like muscle fibres, myofibrils and possibly sarcomeres (Gabbott et al., 1995). These indicate that conodont animals were sprinters, not marathon runners. A morphologically distinct conodont animal, Panderodus unicostatus, has been discovered in lower Silurian strata (Mikulic et al., 1985). This animal is poorly preserved, but appears to be dorso-ventrally compressed; importantly, the head contains well-preserved coniform conodont elements (Smith et al., 1987).

The anatomy of these animals, plus ultrastructural studies of the elements (Sansom et al., 1992), have placed the conodonts firmly within the Chordata. The conodont element is the primitive product of vertebrate tissue mineralization and consists of a denticle formed from a lamellar crown composed of an enamel homologue and dentine basal body (Sansom et al., 1992; Donoghue \& Sansom, 2002). Derived conodonts grew by appositional growth that may have been entrained by tidal, lunar or seasonal cycles (Zhang et al., 1997; Donoghue, 1998; Armstrong \& Smith, 2001; Armstrong, 2005). 
Functional modelling (Aldridge et al., 1987; Purnell \& Donoghue, 1998), growth studies (Armstrong \& Smith, 2001; Armstrong, 2005) and the discovery of microwear facets (Purnell, 1995) on the denticles of some elements support a grasping and processing function for the apparatus. The reconstruction of the Panderodus apparatus (Sansom et al., 1994) suggests a similar function for this group of 'coniform' conodonts. If conodonts represent a monophyletic group then it is likely only a small number of apparatus baupläne existed, in much the same way as only a few basic dentitions, relating to feeding style occur in mammals.

\section{Advances in classification}

The suprageneric classification of conodonts (Aldridge \& Smith, 1993; Sweet, 1988) is, at best, considered provisional and has many limitations, not least that the apparatuses of many taxa are incompletely known, that almost all have not been proven in natural assemblages and that the scheme is not based upon cladistic or other classificatory methods. Under this scheme the Conodonta would appear to be a grade of organization acquired independently in the ancestral Upper Cambrian Teridontus and Proconodontus lineages (Sweet \& Donoghue, 2001). Cladistic analysis of primitive vertebrates indicates conodonts are best considered monophyletic stem group gnathostomes, though they lacked jaws (Donoghue et al., 2000).

\section{Advances in palaeoecology, palaeobiogeography and palaeoclimate}

Conodonts were exclusively marine, occurring in a wide range of habitats from hypersaline to bathyal, even abyssal. The group underwent rapid ecological and phylogenetic differentiation during the Early Ordovician (Smith et al., 2002). Recent work on the distribution of Middle and Upper Ordovician conodonts supports ecological differentiation into continental-shelf communities - largely nektobenthonic - and oceanic communities, dominated by epipelgaic taxa. There is no simple correlation between continental-shelf shelly and conodont biofacies and the primary ecological controlling factors of these conodonts remain unclear. But the fact that conodonts show marked provincialism at various times in their history suggests they were sensitive to temperature. Fundamental distinctions in these communities occur at the order level, suggesting differences in apparatus architecture and element morphologies reflect differences in habitat and mode of life (Armstrong \& Owen, 2002). Species within the oceanic realm apparently show depth stratification and or adaptation to specific water masses (Armstrong \& Owen, 2002).

High resolution conodont element geochemistry (trace element and stable isotopes) is being used increasingly to parameterize Palaeozoic climate and oceanography models (e.g. Wright et al., 1984; Keto \& Jacobsen, 1987; Holmden et al., 1996; Veizer et al., 1986, 1997, 1999; Joachimski \& Buggisch, 2002; Wright \& Barnes, 2002; Joachimski et al., 2006).

The new research frontiers lie in the areas of palaeobiology, phylogeny, the testing of evolutionary hypotheses and Palaeozoic environmental change. We should not forget, however, that these areas are entirely reliant upon sound alpha taxonomy based on painstaking collecting and description; we are as 'pigmaei gigantum humeris impositi plusquam ipsi gigantes vident'.

\section{SILICOFOSSILS (DAVID LAZARUS \& RAINER GERSONDE)}

\section{Radiolaria: introduction (David Lazarus)}

Radiolarian research includes basic work on their taxonomy and biology and application of this knowledge to problems in stratigraphy, tectonics, palaeoceanography and understanding biological evolution. Recent reviews of radiolarian research include those by Casey (1987), De Wever et al. (2001) and Lazarus (2005, in press). Radiolarian research grew rapidly in the late 1970 s/early 1980 s, from $c$. 50 titles per year in the mid-1970s and earlier to $c$. 100 titles annually by the early $1980 \mathrm{~s}$.

Output has remained steady at this level ever since. The Mesozoic receives the most attention (46\% of published papers $\left.^{1}\right)$, followed by the Cenozoic (32\%), Palaeozoic (17\%) and Recent (5\%). All major topics were well established by 1980, but how much progress has there been in each area?

\section{Taxonomy (30\% of published papers)}

Despite numerous good studies in the last 25 years, taxonomy is still very incomplete and unclear. Most Cenozoic radiolarian species are still not described, although plenty of well-preserved material is available. More complete description of faunas is still hindered by the lack of comprehensive catalogues and by Haeckel's largely unrevised highly artificial generic framework, despite progress at individual genus-level groups. Mesozoic and Palaeozoic workers have not had such a difficult historical legacy. However, these faunas are also incompletely described due to incomplete and highly variable preservation, and by taxonomic losses from common lab preparation techniques (Blome \& Reed, 1993). Catalogues for Mesozoic-Palaeozoic forms are better developed (e.g. Baumgartner et al., 1995) and, although not comprehensive, they have improved the quality and efficiency of taxonomic work. The outlook for taxonomy in the next decades depends on the development of better tools large taxonomic databases (Neptune: Lazarus, 1994; Radworld: Caulet et al., 2006) and improving communication between workers via the Internet. Also important will be re-examination of the historic Ehrenberg and Haeckel collections (Suzuki et al., 2006), access to which has improved dramatically since the late 1990s (Lazarus, 2000). The higherlevel systematics of radiolarians is still largely unknown, although the extreme disparity in baupläne morphologies in radiolarians allows reasonable suppositions about most familylevel taxa (e.g. De Wever et al., 2001). We still lack any real knowledge of the biological basis of morphological characters, which is needed to develop robust higher-level systematic hypotheses. Genetic studies of radiolarians have begun to appear (Amaral-Zettler et al., 1999; Yuasa et al., 2006) and should hopefully in the next years provide a solid foundation on which to base higher-level radiolarian taxonomy and systematics.

${ }^{1}$ Numerical analysis of literature based on Sanfilippo et al. (2000) and keyword classification given there. Individual papers with multiple theme assignments treated as multiple papers for calculations, total for papers since 1980 is 1545); unclassified/other theme papers (c. $40 \%$ of total, mostly non-English publications) excluded from totals. Geological time interval percentages calculated separately. More recent literature lists from www.radiolaria.org and its Interrad newsletter archive were examined to check for any changes in trends; none were noticed.) 
Stratigraphy (plus tectonics, $47 \%$ of published papers)

Major stratigraphical advances have been made over the last 25 years. In 1980, a complete Cenozoic low-latitude zonation existed (Riedel \& Sanfilippo, 1978; Sanfilippo et al., 1985); but only partial zonations for most other time intervals or regions. In 2006 we now have an almost complete zonation for the entire Phanerozoic, much of it based on global markers and, in some cases (e.g. Cenozoic), also with additional regional markers and moderate-good calibration to geochronology (see summary in De Wever et al., 2001). The next 25 years should yield additional resolution from the use of more species as markers and better calibration to geochronology. Diachroneity and limits to taxonomic precision will eventually, however, limit further increase in the precision or accuracy of zonations. Many stratigraphical studies will continue to be combined with tectonics to help understand the origin of complex terranes.

\section{Palaeoceanographic research (12\% of published papers)}

In the Quaternary there has been continued use of quantitative calibration of assemblages to modern ocean conditions for palaeotemperature estimation (e.g. Pisias et al., 1997; Abelmann et al., 1999), but the number of such studies was not very high. Future Quaternary palaeoenvironmental studies may also focus on using radiolarians to estimate other ocean characteristics, particularly productivity. A low-latitude upwelling index was developed in the 1990s (Caulet et al., 1992; Nigrini \& Caulet, 1992) and current work on a water-depth ecology ('WADE') method (Lazarus, 2005; Lazarus et al., 2006) may be applicable more generally. Pre (late) Neogene palaeoenvironmental work is still limited by the lack of direct ecological information for extinct taxa and our inability, due to our lack of basic biological knowledge, to estimate the ecology of extinct species from their taxonomy and morphology. A few qualitative studies using radiolarian biogeography as water-mass tracers were, however, published (Pessagno \& Blome, 1986; Lazarus \& Caulet, 1994; Kiessling, 1999).

\section{Biology ( $7 \%$ of published papers)}

Biological knowledge of radiolarians has improved greatly in the last 25 years. Anderson (1983) provided a landmark summary of his research group's study of radiolarian biology. Water column studies have provided at least preliminary information on the depth ecology for many modern taxa (e.g. Boltovskoy \& Riedel, 1987; Abelmann \& Gowing, 1996; Yamashita et al., 2002) and more information on how taphonomy affects the fossil record (Takahashi, 1991; Welling \& Pisias, 1998); while continued laboratory studies have added more information on basic cell behaviour. There is still, however, very much more to do in all of these areas and, in particular, on the functional ecology (especially the shell) of both taxonomic groups and individual species. Given that such knowledge would yield major benefits to palaeoenvironmental studies, particularly for extinct species, hopefully this topic will be better developed in coming decades. Methods, however, are still needed to maintain radiolarians in continuous culture and a long-term programme to study the ecology of individual specimens in the water column is required as well.

\section{Evolution (4\% of published papers)}

Microevolution (speciation) case studies, begun in the 1970s, have continued (e.g. Lazarus, 1986) and contributed, albeit in a minor way, to the great 'punctuated equilibrium' debate in the early 1980s. Further advances in speciation research, however, will require better knowledge of species concepts (particularly in light of potential cryptic species, widely documented in other plankton groups) and the ecology of the studied taxa. Macroevolution research largely has not yet been carried out for radiolarians, despite a superb record of evolutionary change that can be compared accurately to coeval environmental history. Stratigraphic work has already shown distinctive patterns of radiolarian response to mass-extinction events at both the $\mathrm{KT}$ (Hollis, 1997) and PT boundaries (Kamata et al., 2006). As tools such as databases and higher-level taxonomy improve, understanding the evolutionary mechanisms behind macroevolutionary patterns will be a major opportunity for new research in the next decades.

\section{Organizational aspects}

The last 25 years saw dramatic improvements in the social aspects of radiolarian research. In the 1980s the international radiolarian community coalesced into the Interrad Society, with regular congresses and an annual newsletter. Radiolarian workers also enjoy one of the best community websites in micropalaeontology at www.radiolaria.org (Dolven \& Skjerpen, 2000-2006). Radiolarian workers, however, are still somewhat under-represented in other micropalaeontology societies, such as TMS, which recognized this fact and founded the Silicofossil Group in 1997.

\section{Personalia/teaching/training}

Many of the pioneers of modern radiolarian research, who in the 1950s and 1960s helped develop the field, have now retired, but their students are still active and continue to train new workers. Teaching continues to be done mostly by the relatively small number of radiolarian workers holding university teaching posts. Radiolarian specialists continue to be under-represented in academic departments, as micropalaeontology positions are still often combined with carbonate geochemistry (e.g. foraminifera and stable isotopes). One can only hope that more teaching positions will be filled by radiolarian workers. There are still many more opportunities to use radiolarians to solve important geological and biological problems than there are radiolarian workers to use them!

\section{Fossil diatoms: introduction (Rainer Gersonde)}

The 25 last years, which followed the introduction of marine and fresh-water diatoms as stratigraphical and palaeoenvironmental markers since the mid-1950s, have seen consolidation and further improvement, as well as development of new methods for extracting information from fossil diatoms. Much of the marine work has been accomplished on diatom records recovered with the drillship, JOIDES Resolution, within the Deep Sea Drilling Project (DSDP) (1968-1983) and Ocean Drilling Program (ODP) (1985-2003).

\section{Biostratigraphy}

Advanced coring techniques available since the late stage of DSDP provided sediment sequences at high recovery rates, 
permitting remarkable detailing of Cenozoic diatom species ranges and stratigraphical zonations for the North and Equatorial Pacific (Barron, 1980, 1981, 1985a; Gladenkov \& Barron, 1995; Maruyama, 2000), the Atlantic (Baldauf, 1984, 1987; Fenner, 1984; Koc et al., 1999) and the Southern Ocean (Gersonde \& Burckle, 1990; Harwood \& Maruyama, 1992; Censarek \& Gersonde, 2002; Zielinski \& Gersonde, 2002). The quality of the sediment cores further allowed the linking of diatom stratigraphies to geomagnetic and oxygen isotope stratigraphies. Such absolute dating of diatom ranges has provided the baseline for palaeoceanographic interpretation of the spatial distribution of diatom species and improved our understanding of Cenozoic diatom evolution and the mechanisms related to it.

\section{Origin and evolution of diatoms}

The recovery of extraordinarily well-preserved Early Cretaceous diatom assemblages (c.110 Ma) on the Antarctic margin (ODP Site 693) provided the first comprehensive view of critical steps of early diatom evolution (Gersonde \& Harwood, 1990; Harwood \& Gersonde, 1990). These include the transformation of valve shape from cylindrical to discoid, and of the outline from circular to bipolar, and the development of specific structures (processes, protulae) that replace heavily silicified linking structures used for chain formation. Diatom evolution before $110 \mathrm{Ma}$ and during the Late Cretaceous still remains largely unknown. Late Cretaceous (after $90 \mathrm{Ma}$ ) and Paleocene diatoms have been reported only from a few sites to date (e.g. Barron, 1985b; Harwood, 1988; Dell'Anglese \& Clark, 1994; Tapia \& Harwood, 2002). Because of the limited number of records the effect of the asteroid impact at the Cretaceous-Tertiary (KT) boundary $(65 \mathrm{Ma})$ on diatom evolution remains unresolved. While Harwood (1988) concluded that $84 \%$ of the species survived the KT, Chambers (1996) estimated the survival rate to be only about $37 \%$. Extensive documentation of diatom evolution considering the fossil record and molecular biological evidence has recently been presented by Sims et al. (2006) and Kooistra et al. (in press).

\section{Diatom palaeoecology and isotope studies}

During the past 15 years, major progress has been made in the application of diatoms to estimate past marine and fresh-water environmental conditions. This includes demonstrating the utility of diatoms as indicators of environmental parameters, including temperature, salinity, productivity regimes, sea ice, water chemistry and water level, and developing extensive reference datasets supporting quantitative reconstructions via transfer functions techniques (e.g. Gasse et al., 1995; Pienitz et al., 1995; Bigler \& Hall, 2002; Fallu et al., 2002; Andersen et al., 2004; Crosta et al., 1998; Zielinski et al., 1998). Quantitative palaeoenvironmental estimations from fresh-water deposits have been focused on documenting the past 20000 30000 years (e.g. Barber et al., 1999; Chalié \& Gasse, 2002; Heiri \& Lotter, 2005). Reconstructions of the marine surface water properties (e.g. temperature, sea ice) include the study of specific time slices (e.g. the Last Glacial Maximum, Gersonde et al., 2005), as well as Quaternary and Tertiary time series studies at various different temporal resolutions and time series that document surface water parameters at various ranges of time resolution from Quaternary and Tertiary records (e.g.
Cunningham et al., 1999; Lange et al., 1999; Koizumi et al., 2004; Bianchi \& Gersonde, 2004; Domack et al., 2005)

New stable isotope methods utilizing geochemistry on diatom opal $\left(\delta^{30} \mathrm{Si}, \delta^{30} \mathrm{O}\right)$ and organic matter trapped within $\left(\delta^{30} \mathrm{C}\right.$, $\delta^{30} \mathrm{~N}$ ) have been established during the past decade. They serve as proxies for nutrient utilization or surface water temperature or salinity (e.g. melt-water input or moisture balance (Shemesh et al., 1994; De La Rocha et al., 1998; De La Rocha, 2006; Rietti-Shati et al., 1998; Sigman et al., 1999; Barker et al., 2001). The longest record showing $\delta^{30} \mathrm{C}$ and $\delta^{30} \mathrm{~N}$ measurements, together with diatom-derived surface temperature and sea ice estimates, covers the past 650000 years in the Southern Ocean (Schneider-Mor et al., 2005).

\section{What next?}

Future efforts in diatom research should consider further developments in diatom-based proxies for the description of past environmental development, using species composition and biometry, as well as geochemical and stable isotope composition. Taxonomic, stratigraphical and autecological information on diatoms should be collected and disseminated via international data repositories to avoid loss of information gathered in the past 50 years in a scientific environment that increasingly relies on electronic media.

\section{Manuscript received 1 May 2006 Manuscript accepted 1 August 2006}

\section{REFERENCES (laid out according to TMS Groups)}

\section{Ostracod references}

Bate, R.A. \& Robinson, E. 1978. A Stratigraphical Index of British Ostracoda. John Wiley \& Sons Ltd, Chichester, 400pp.

Chivas, A., De Deckker, P. \& Shelley, J. 1983. Magnesium, strontium, and barium partitioning in nonmarine ostracode shells and their use in paleoenvironmental reconstructions - a preliminary study. In: Maddocks, R.F. (Ed.), Applications of Ostracoda. University of Houston Geosciences, Houston, 238-249.

Chivas, A., De Deckker, P. \& Shelley, J. 1986a. Magnesium and strontium in non-marine ostracod shells as indicators of palaeosalinity and palaeotemperature. Hydrobiologia, 143: 135-142.

Chivas, A., De Deckker, P. \& Shelley, J. 1986b. Magnesium content of non-marine ostracod shells: a new palaeosalinometer and palaeothermometer. Palaeogeography, Palaeoclimatology, Palaeoecology, 54: 43-61.

Cronin, T.M. \& Raymo, M.E. 1997. Orbital forcing of deep-sea benthic species diversity. Nature, 385: 624-627.

De Deckker, P. 2002. Ostracode Palaeoecology. In: Holmes, J.A. \& Chivas, A. (Eds), The Ostracoda: Applications in Quaternary Research. American Geophysical Union Monograph, 131: 125-132.

Dwyer, G.S., Cronin, T.M., Baker, P.A., et al. 1995. North Atlantic deepwater temperature change during late Pliocene and late Quaternary climatic cycles. Science, 270: 1347-1351.

Dwyer, G.S., Cronin, T.M. \& Baker, P.A. 2002. Trace elements in marine ostracodes. In: Holmes, J.A. \& Chivas, A.R. (Eds), The Ostracoda: Applications in Quaternary Research. American Geophysical Union Monograph, 131: 205-226.

Forester, R.M., Smith, A.J., Palmer, D.F. \& Curry, B.B. 2005. North American Non-Marine Ostracode Database Version 1 'NANODe'. Available at http://www.kent.edu/nanode (December, 2005, Kent State University).

Horne, D.J., Baltanás, A. \& Paris, G. 1998. Geographical distribution of reproductive modes in living non-marine ostracods. In: Martens, K. (Ed.), Sex and parthenogenesis: evolutionary ecology of reproductive modes in non-marine ostracods. Backhuys, Leiden, 77-99. 
Hou Xianguang, Siveter, D.J., Williams, M., Walossek, D. \& Bergström, J. 1996. Appendages of the arthropod Kunmingella from the early Cambrian of China: its bearing on the systematic position of the Bradoriida and the fossil record of the Ostracoda. Philosophical Transactions of the Royal Society London, B, 351: 1131-1145.

Kempf, E.K. 1996. Index and Bibliography of Marine Ostracoda 9: Bibliography C. Sonderveroeffentlichungen des Geologischen Instituts der Universitaet zu Koeln, 103: 1-198.

Kempf, E.K. 1997. Index and Bibliography of Nonmarine Ostracoda 9: Bibliography C. Sonderveroeffentlichungen des Geologischen Instituts der Universitaet zu Koeln, 112: 1-150.

Keyser, D. \& Walter, R. 2004. Calcification in ostracodes. Revista Española de Micropaleontología, 36 (1): 1-11.

Maas, A., Waloszek, D. \& Müller, K.J. 2003. Morphology, Ontogeny and Phylogeny of the Phosphatocopina (Crustacea) from the Upper Cambrian 'Orsten' of Sweden. Fossils and Strata, 49: 1-238.

Martens, K., Rossetti, G. \& Horne, D.J. 2003. How ancient are ancient asexuals? Proceedings of the Royal Society of London, series B (Biological Sciences), 270: 723-729.

Siveter, D.J. 1984. Habitats and modes of life of Silurian Ostracodes. In: Bassett, M.G. \& Lawson, J.D. (Eds), The Autecology of Silurian Organisms. Special Papers in Palaeontology, 32: 71-85.

Siveter, D.J., Vannier, J.M.C. \& Palmer, D. 1987. Silurian myodocopid ostracodes: their depositional environments and the origin of their shell microstructures. Palaeontology, 30: 783-813.

Siveter, D.J., Vannier, J.M.C. \& Palmer, D. 1991. Silurian myodocopes: pioneer pelagic ostracodes and the chronology of an ecological shift. Journal of Micropalaeontology, 10: 151-173.

Siveter, D.J., Williams, M. \& Walossek, D. 2001. A phosphatocopid crustacean with appendages from the lower Cambrian. Science, 293: 479-481.

Siveter, David J., Sutton, M., Briggs, D.E.G. \& Siveter, Derek J. 2003. An ostracode crustacean with soft parts from the Lower Silurian. Science, 302: 1747-1751.

Smith, R.J., Kamiya, T. \& Horne, D.J. 2006. Living males of the 'ancient asexual' Darwinulidae (Ostracoda: Crustacea). Proceedings of the Royal Society of London, series B (Biological Sciences), 273: $1569-1578$.

von Grafenstein, V. 2002. Oxygen-isotope studies of ostracods from deep lakes. In: Holmes, J.A. \& Chivas, A. (Eds), The Ostracoda: Applications in Quaternary Research. American Geophysical Union Monograph, 131: 249-266.

von Grafenstein, V., Erlenkeuser, H., Bramer, A., Jonzel, J. \& Johnsen, S.J. 1999. A mid-European decadal isotope - climate record from 15,500 to 5000 years B.P. Science, 284: 1654-1657.

\section{Foraminifera references}

Bé, A.W.H. 1977. An ecological, zoogeographic and taxonomic review of Recent planktonic foraminifera. In: Ramsay, A.T.S. (Ed.), Oceanic Micropaleontology. Academic Press, London, 1-100.

Cavalier Smith, T. 1993. Kingdom Protozoa and its 18 Phyla. Microbiological Reviews, 57: 953-994.

CLIMAP Project Members 1981. Seasonal reconstruction of the earth's surface at the last glacial maximum. Geological Society of America Map and Chart Series, 36.

Corliss, B.H. 1985. Microhabitats of benthic foraminifera within deepsea sediments. Nature, 314 (6010): 435-438.

Darling, K.F., Wade, C.M., Stewart, I., et al. 2000. Molecular evidence for genetic mixing of Arctic and Antarctic subpolar populations of planktonic foraminifers. Nature, 405: 43-47.

Darling, K.F., Kucera, M., Pudsey, C.J. \& Wade, C.M. 2004. Molecular evidence links cryptic diversification in polar planktonic protists to Quaternary climate dynamics. Proceedings of the National Academy of Science, 101 (20): 7657-7662.

Delaney, M.L. \& Boyle, E.A. 1987. Cd/Ca in Late Miocene Benthic Foraminifera and Changes in the Global Organic-Carbon Budget. Nature, 330 (6144): 156-159.

de Vargas, C., Renaud, S., Hilbrecht, H. \& Pawlowski, J. 2001. Pleistocene adaptive radiation in Globorotalia truncatulinoides: genetic, morphologic and environmental evidence. Paleobiology, 27 (1) 104-125.
Gooday, A.J. \& Lambshead, P.J.D. 1989. Influence of seasonally deposited phytodetritus on benthic foraminiferal populations in the bathyal northeast Atlantic: the species response. Marine Ecology Progress Series, 58: 53-67.

Hemleben, C., Spindler, M. \& Anderson, O.R. 1989. Modern Planktonic Foraminifera. Springer, New York, 363pp.

Herguera, J.C. \& Berger, W.H. 1991. Paleoproductivity from benthic foraminifera abundance: Glacial to postglacial change in the west-equatorial Pacific. Geology, 19: 1173-1176.

Huber, B.T., Bijma, J. \& Darling, K. 1997. Cryptic speciation in the living planktonic foraminifer Globigerinella siphoniphera (d'Orbigny). Paleobiology, 23 (1): 33-62.

Imbrie, J., Hays, J.D., Martinson, D.G., et al. 1984. The orbital theory of Pleistocene climate: support from a revised chronology of the marine d 180 record. In: Berger, A.L., et al. (Eds), Milankovitch and Climate. D. Riedel Publications, Dordrecht, 269-305.

Jones, R.W. 1994. The Challenger Foraminifera. Oxford University Press, Oxford, 149pp.

Jorissen, F.J. 1999. Benthic foraminiferal microhabitats below the sediment-water interface. In: Sen Gupta, B.K. (Ed.), Ecology of recent foraminifera. Kluwer Academic Publishers, Amsterdam, 161-179.

Kaiho, K. 1994. Benthic foraminiferal dissolved-oxygen index and dissolved-oxygen levels in the modern ocean. Geology, 22 (8): 719-722.

Loeblich, A.R. Jr \& Tappan, H. 1987. Foraminiferal genera and their Classification. Van Nostrand Rheinhold Company, New York, 970pp.

Lutze, G.F. \& Coulbourn, W.T. 1984. Recent benthic foraminifera from the continental margin of northwest Africa: community structure and distribution. Marine Micropaleontology, 8: 361-401.

Malmgren, B.A., Berggren, W.A. \& Lohman, G.P. 1983. Evidence for punctuated gradualism in the Late Neogene Globorotalia tumida lineage of planktonic foraminifera. Paleobiology, 9 (4): 377-389.

Mix, A. 1989. Pleistocene paleoproductivity: evidence from organic carbon and foraminiferal species. In: Berger, W.H., Smetacek, V.S. \& Wefer, G. (Eds), Productivity in the Ocean: Present and Past. John Wiley \& Sons, New York, 313-340.

Morkhoven, F.P.C.M.v., Berggren, W.A. \& Edwards, A. 1986. Cenozoic benthic deep water foraminifera. Bulletin Centre de Recherché Exploration-Production, 11: 1-421.

Murray, J.W. 1973. Distribution and Ecology of Living Benthic Foraminiferids. Heinemann Educational Books, London, 274pp.

Pearson, P.N. \& Palmer, M.R. 2000. Atmospheric carbon dioxide concentrations over the past 60 million years. Nature, 406 (6797): 695-699.

Scott, D.B. \& Medioli, F.S. 1980. Quantitative studies of marsh Foraminiferal Distributions in Nova Scotia: implications for sea-level research. Cushman Foundation for Foraminiferal Research, Special Publication, 17: 1-58.

Shackleton, N.J., Berger, A. \& Pettier, W.R. 1990. An alternative astronomical calibration of the lower Pleistocene timescale based on ODP Site 677. Philosophical Transaction of the Royal Society of Edinburgh, Earth Science, 81: 251-261.

Vincent, E., Killingley, J.S. \& Berger, W.H. 1981. Stable Isotope Composition of Benthic Foraminifera from the Equatorial Pacific. Nature, 289 (5799): 639-643.

\section{Palynology references}

Achab, A., Asselin, E., Lavoie, D. \& Mussard, J.M. 1997. Chitinozoan assemblages from the third-order transgressive cycles of the Upper Gaspé Limestones (Lower Devonian) of eastern Canada. Review of Palaeobotany and Palynology, 97: 155-175.

Achab, A., Asselin, E. \& Liang, B. 2000. Relational databases and image acquisition systems in support of palynological studies: the CHITINOS concept. Review of Palaeobotany and Palynology, 113: $15-26$.

Arouri, K.R., Greenwood, P.F. \& Walter, M.R. 2000. Biological affinities of Neoproterozoic acritarchs from Australia: microscopic and chemical characteristics. Organic Geochemistry, 31: 75-89.

Balme, B.E. 1995. Fossil in situ spores and pollen grains: an annotated catalogue. Review of Palaeobotany and Palynology, 87: 81-323. 
Batten, D.J. 1996a. Palynofacies and palaeoenvironmenta interpretation. In: Jansonius, J. \& McGregor, D. (Eds), Palynology: principles and applications. American Association of Stratigraphic Palynologists Foundation: 1011-1064.

Batten, D.J. 1996b. Palynofacies and petroleum potential. In: Jansonius, J. \& McGregor, D. (Eds), Palynology: principles and applications. American Association of Stratigraphic Palynologists Foundation: 1065-1084.

Batten, D.J. \& Dutta, R.J. 1997. Ultrastructure of exine of gymnospermous pollen grains from Jurassic and basal Cretaceous deposits in Northwest Europe and implications for botanical relationships. Review of Palaeobotany and Palynology, 99: 25-54.

Brenner, G.J. 1996. Evidence for the earliest stage of angiosperm pollen evolution: a palaeoequatorial section from Israel. In: Taylor, D.W. \& Hickey, L.J. (Eds), Flowering plant origin, evolution and phylogeny. Chapman \& Hall, New York, 91-115.

Brinkhuis, H., Schouten, S., Collinson, M.E., et al. \& the Expedition 302 Scientists. 2006. Episodic fresh surface waters in the Eocene Arctic Ocean. Nature, 441: 606-609.

Cornet, B. 1989. Late Triassic angiosperm-like pollen from the Richmond Rift Basin of Virginia, U.S.A. Palaeontographica, Abt. B, 213: 37-87.

Crouch, E.M. \& Brinkhuis, H. 2005. Environmental change across the Paleocene-Eocene transition from eastern New Zealand: a marine palynological approach. Marine Micropalaeontology, 56: 138-160.

D'Iorio, M.A. 1986. Integration of forminiferal and dinoflagellate data sets in quantitative stratigraphy of the Grand Banks and Labrador Shelf. Bulletins of Canadian Petroleum Geology, 34: 277-283.

Dale, A.L. \& Dale, B. 2002. Application of ecologically based statistical treatments to micropalaeontology. In: Haslett, S.K. (Ed.), Quaternary environmental micropalaeontology. Arnold, London, 259-286.

Davies, J.R., McNestry, A. \& Waters, R.A. 1991. Palaeoenvironments and palynofacies of a pulsed transgression: the Late Devonian and Early Dinantian (Lower Carboniferous) rocks of south-east Wales. Geological Magazine, 28: 355-380.

de Leeuw, J.W. \& Largeau, C. 1993. A review of macromolecular compounds that comprise living organisms and their role in kerogen, coal and petroleum formation. In: Engel, M.H. \& Macko, S.A. (Eds), Organic geochemistry, principles and applications. Plenum Press, New York, 23-72.

Downie, C. 1984. Acritarchs in British stratigraphy. Geological Society, London, Special Reports, 17: 26pp.

Edwards, L.E. 1989. Supplemented graphic correlation; a powerful too for paleontologists and nonpaleontologists. Palaios, 4 (2): 127-143.

Eldrett, J.S., Harding, I.C., Firth, J.V. \& Roberts, A.P. 2004. Magnetostratigraphic calibration of Eocene-Oligocene dinoflagellate cyst biostratigraphy from the Norwegian-Greenland Sea. Marine Geology, 204: 91-127.

Ellegaard, M., Daubjerg, N., Rochon, A., Lewis, J. \& Harding, I. 2003. Morphological and LSU rDNA sequence variation within the Gonyaulax spinifera- Spiniferitesgroup (Dinophyceae) and proposal of Gonyaulax elongata comb. nov. and G. membranacea comb. nov. Phycologia, 42 (2): 151-164.

Evitt, W.R. 1985. Sporopollenin dinoflagellate cysts: their morphology and interpretation. American Association of Stratigraphic Palynologists, Austin, Texas: 333pp.

Evitt, W.R., Damassa, S.P. \& Albert, N.R. 1998. Tiger by the tail: the exophragm of the Cretaceous-Paleocene dinoflagellate Palaeoperidiniumand its implications. Palynology, 22: 1-55.

Fensome, R.A. \& Williams, G.L. 2004. The Lentin and Williams index of fossil dinoflagellates, 2004 edition. American Association of Stratigraphic Palynologists, Contributions Series, 42: 909pp.

Fensome, R.A., Williams, G.L., Barss, M.S., Freeman, J. \& Hill, J.M 1990. Acritarchs and fossil prasinophytes: an index to genera, species and intraspecific taxa. American Association of Stratigraphic Palynologists, Contributions Series, 25: 771pp.

Fensome, R.A., Taylor, F.J.R., Norris, G., et al. 1993. A classification of living and fossil dinoflagellates. Micropalaeontology Special Publication, 7: $351 \mathrm{pp}$.

Fensome, R.A., McRae, R.A., Moldowan, J.M., Taylor, F.J.R. \& Williams, G.L. 1996. The early Mesozoic radiation of dinoflagellates. Paleobiology, 22: 329-338.
Friis, E.M., Pedersen, K.R. \& Crane, P.R. 2006. Cretaceous angiosperm flowers: innovation and evolution in plant reproduction. Palaeogeography, Palaeoclimatology, Palaeoecology, 232: 251-293.

Gabarayeva, N. \& Hemsley, A.R. 2006. Merging concepts: the role of self-assembly in the development of pollen wall structure. Review of Palaeobotany and Palynology, 138: 121-139.

Gorin, G.E. \& Steffen, D. 1991. Organic facies as a tool for recording eustatic variations in marine fine-grained carbonate - example of the Berriasian stratotype at Berrias (Ardèche, France). Palaeogeography, Palaeoclimatology, Palaeoecology, 85: 303-320.

Grice, K., Backhouse, J., Alexander, R., Marshall, N. \& Logan, G.A. 2005. Correlating terrestrial signatures from biomarker distributions, $\delta^{13} \mathrm{C}$, and palynology in fluvio-deltaic deposits from NW Australia (Triassic-Jurassic). Organic Geochemistry, 36: 1347-1358.

Harland, R. 1983. Distribution maps of recent dinoflagellate cysts in bottom sediments from the North Atlantic Ocean and adjacent seas. Palaeontology, 26 (2): 321-387.

Hart, G.F., Pasley, M.A. \& Gregory, W.A. 1994. Particulate organic matter, maceral facies models, and applications to sequence stratigraphy. In: Traverse, A. (Ed.), Sedimentation of organic particles. Cambridge University Press, Cambridge, 337-390.

Hochuli, P.A. \& Feist-Burkhardt, S. 2004. A boreal early cradle of angiosperms? Angiosperm-like pollen from the Middle Triassic of the Barents Sea (Norway). Journal of Micropalaeontology, 23: 97-104.

Huber, M., Brinkhuis, H., Stickley, C.E., et al. 2004. Eocene circulation of the Southern Ocean: Was Antarctica kept warm by subtropical waters? Paleoceanography, 19: PA4026.

Hughes, N.F. 1994. The enigma of angiosperm origins. Cambridge University Press, Cambridge, 303pp.

Jansonius, J. \& McGregor, D. 1996. Palynology: principles and applications. 3 volumes. American Association of Stratigraphic Palynologists Foundation, Austin, Texas.

Jones, T.P. \& Rowe, N.P. 1999. Fossil Plants and Spores: modern techniques. Geological Society, London, 396pp.

Katz, B. \& Pratt, L. 1993. Source rocks in a sequence stratigraphic framework. AASP Studies in Geology, 37: 247pp.

Kokinos, J.P. \& Anderson, D.M. 1995. Morphological development of resting cysts in cultures of the marine dinoflagellate Lingulodinium polyedrum (=L. machaerophorum). Palynology, 19: 143-166.

Lentin, J.K. \& Williams, G.L. 1973. Fossil dinoflagellates: index to genera and species. Geological Survey of Canada, Paper, 73-42: 176pp.

Liang, M.-M., Bruch, A., Collinson, M., et al. 2003. Testing the climatic estimates from different palaeobotanical methods: an example from the Middle Miocene Shanwang flora of China. Palaeogeography, Palaeoclimatology, Palaeoecology, 198: 279-301.

Lupia, R. 1999. Discordant morphological disparity and taxonomic diversity during the Cretaceous angiosperm radiation: North American pollen record. Paleobiology, 25 (1): 1-28.

Marret, F. \& Zonneveld, K.A.F. 2003. Atlas of modern organic-walled dinoflagellate distribution. Review of Palaeobotany and Palynology, 125: $1-200$.

Marshall, C.P., Javaux, E.J., Knoll, A.H. \& Walter, M.R. 2005. Combined micro-Fourier transform infrared (FTIR) spectroscopy and micro-Raman spectroscopy of Proterozoic acritarchs: a new approach to palaeobiology. Precambrian Research, 138: 208-224.

Marshall, J.E.A. 1991. Quantitative spore colour. Journal of the Geological Society, London, 148 (2): 223-233.

Moldowan, J.M. \& Talyzina, N.M. 1998. Biogeochemical evidence for dinoflagellate ancestors in the early Cambrian. Science, 281: $1168-1169$.

Mosbrugger, V. \& Utescher, T. 1997. The coexistence approach - a method for quantitative reconstructions of Tertiary terrestrial palaeoclimate data using plant fossils. Palaeogeography, Palaeoclimatology, Palaeoecology, 134: 61-86.

Mudie, P.J. 1992. Circum-Arctic Quaternary and Neogene marine palynofloras: paleoecology and statistical analysis. In: Head, M.J. \& Wren, J.H. (Eds), Neogene and Quaternary Dinoflagellate Cyst. American Association of Stratigraphic Palynologists Contributions: 347-390.

Mullins, G.L., Aldridge, R.J. \& Siveter, D.J. 2004. Microplankton associations, biofacies and palaeoenvironment of the type lower 
Ludlow Series, Silurian. Review of Palaeobotany and Palynology, 130 163-194.

Nicholls, D.J. 2003. Biodiversity changes in Cretaceous palynofloras of eastern Asia and western North America. Journal of Asian Earth Sciences, 21: 823-833.

Obermajer, M., Stasiuk, L.D., Fowler, M.G. \& Osadetz, K.G. 1999. Application of acritarch fluorescence in thermal maturity studies. International Journal of Coal Geology, 39: 185-185.

Overpeck, J.T., Webb, R.S. \& Webb, T. 1992. Mapping eastern North American vegetation change of the past 18ka: no-analogs and the future. Geology, 20: 1071-1074.

Paris, F. \& Nõlvak, J. 1999. Biological interpretation and paleodiversity of a cryptic fossil group: the 'Chitinozoan animal'. Geobios, 32: 315-324.

Paris, F., Grahn, Y., Nestor, V. \& Lakova, I. 1999. A revised chitinozoan classification. Journal of Paleontology, 73: 549-570.

Paris, F., Winchester-Seeto, T., Boumendjel, K. \& Grahn, Y. 2000. Towards a global biozonation of Devonian chitinozoans. Courier Forschungsinstitut Senckenbergiana, 220: 39-55.

Parry, C.C., Whitley, P.K.J. \& Simpson, R.D.H. 1981. Integration of palynological and sedimentological methods in facies analysis. In: Illing, L.V. \& Hobson, G.D. (Eds), Petroleum Geology of the Continental Shelf of North-west Europe. Heyden, London, 205-215.

Partington, M.A., Copestake, P., Mitchener, B.C. \& Underhill, J.R. 1993. Biostratigraphic correlation of genetic stratigraphic sequences in the Jurassic-lowermost Cretaceous (Hettangian to Ryazanian) of the North Sea and adjacent areas. In: Parker, J.R. (Ed.), Petroleum Geology of Northwest Europe: proceedings of the $4^{\text {th }}$ conference. Geological Society, London, 371-386.

Pearson, S.J., Marshall, J.E.A. \& Kemp, A.E.S. 2004. The White Stone Band of the Kimmeridge Clay Formation, an integrated highresolution approach to understanding environmental change. Journal of the Geological Society, London, 161 (4): 675-683.

Poole, I., Cantrill, D. \& Utescher, T. 2005. A multi-proxy approach to determine Antarctic terrestrial palaeoclimate during the Late Cretaceous and Early Tertiary. Palaeogeography, Palaeoclimatology, Palaeoecology, 222: 95-121.

Powell, A.J. 1992. A Stratigraphic Index of Dinoflagellate Cysts. Chapman \& Hall, London, 290pp.

Qiu, Y.-L. \& Lee, J. 2000. Transition to a land flora: a molecular phylogenetic approach. Journal of Phycology, 36: 799-802.

Rochon, A., de Vernal, A., Turon, J.-L., Matthiessen, J. \& Head, M.J. 1999. Distribution of recent dinoflagellate cysts in surface sediments from the North Atlantic Ocean and adjacent seas in relation to sea-surface parameters. American Association of Stratigraphic Palynologists, Contributions Series, 35: 152pp.

Saldarriaga, J.F., Taylor, F.J.R., Cavalier-Smith, T., Menden-Deuer, S. \& Keeling, P.J. 2004. Molecular data and the evolutionary history of dinoflagellates. European Journal of Protistology, 40: 85-111.

Sinninghe Damsté, J.S. \& de Leeuw, J.W. 1990. Analysis, structure and geochemical significance of organically-bound sulphur in the geosphere: the state of the art and future research. Organic Geochemistry, 16: 1077-1101.

Sluijs, A., Schouten, S., Pagani, M., et al. \& the Expedition 302 Scientists. 2006. Subtropical Arctic Ocean temperatures during the Palaeocene/Eocene thermal maximum. Nature, 441: 610-613.

Spector, D.L. (Ed.) 1984. Dinoflagellates. Academic Press, Inc., Orlando, 545pp.

Stricanne, L., Munnecke, A. \& Pröss, J. 2006. Assessing mechanisms of environmental change: palynological signals across the Late Ludlow (Silurian) positive isotope excursion $\left(\delta^{13} \mathrm{C}, \delta^{18} \mathrm{O}\right)$ on Gotland, Sweden. Palaeogeography, Palaeoclimatology, Palaeoecology, 230: $1-31$.

Strother, P.K. 1996. Acritarchs. In: Jansonius, J. \& McGregor, D.C. (Eds), Palynology: principles and applications. Volume 1. American Association of Stratigraphic Palynologists Foundation, Austin, TX, 81-106.

Sweet, A.R. 1994. Relationships between depositional environments and changes in palynofloras across the K/T boundary. In: Traverse, A. (Ed.), Sedimentation of organic particles. Cambridge University Press, Cambridge, 461-488.
Tappan, H. 1980. The paleobiology of plant protists. W H Freeman \& Co., San Francisco, 1028pp.

Taylor, F.J.R. (Ed.) 1987. The biology of dinoflagellates. Botanical Monographs, 21. Blackwell Scientific Publications, Oxford, 785pp.

Tissot, B.P. \& Welte, D.H. 1984. Petroleum formation and occurrence. Springer, Berlin, 699pp.

Traverse, A. 1988. Paleopalynology. Allen \& Unwin, London, 600pp.

Traverse, A. 1994. Sedimentation of organic particles. Cambridge University Press, Cambridge, 00pp.

Tricker, P.M., Marshall, J.E.A. \& Badman, T.D. 1992. Chitinozoan reflectance: a Lower Palaeozoic thermal maturity indicator. Marine and Petroleum Geology, 9: 302-307.

Tschudy, R.H., Pillmore, C.L., Orth, C.J., Gilmore, J.S. \& Knight, J.D. 1984. Disruption of the terrestrial plant ecosystem at the CretaceousTertiary boundary, Western Interior. Science, 225: 1030-1032.

Tyson, R.V. 1995. Sedimentary organic matter: organic facies and palynofacies. Chapman \& Hall, London, 615pp.

van Bergen, P.F., Blokker, P., Collinson, M.E., Sinninghe Damsté, J.S. \& de Leeuw, J.W. 2004. Structural biomacromolecules in plants: what can be learnt from the fossil record? In: Hemsley, A.R. \& Poole, I. (Eds), Evolution of plant physiology. Elsevier, Amsterdam, 133-154.

Verniers, J., Nestor, V., Paris, F., Dufka, P., Sutherland, S. \& van Grootel, G. 1995. A global chitinozoa biozonation for the Silurian. Geological Magazine, 132: 651-666.

Versteegh, G.J.M. 1994. Recognition of cyclic and non-cyclic environmental changes in the Mediterranean Pliocene: a palynological approach. Marine Micropalaeontology, 23: 147-183.

Versteegh, G.J.M. \& Blokker, P. 2004. Resistant macromolecules of extant and fossil microalgae. Phycological Research, 52: 325-339.

Versteegh, G.J.M. \& Zonneveld, K.A.F. 2002. Use of selective degradation to separate preservation from productivity. Geology, 30: 615-618.

Versteegh, G.J.M., Blokker, P., Wood, G.D., et al. 2004. An example of oxidative polmerization of unsaturated fatty acids as a preservation pathway for dinoflagellate organic matter. Organic Geochemistry, 35: $1129-1139$.

Walker, J.W. \& Walker, A.G. 1984. Ultrastructure of Lower Cretaceous angiosperm pollen and the origin and early evolution of flowering plants. Annals of the Missouri Botanical Garden, 71: 464-521.

Wellman, C.H., Osterloff, P.L. \& Mohluddin, U. 2003. Fragments of the earliest land plants. Nature, 425: 282-285.

Williams, G.L. \& Bujak, J.P. 1985. Mesozoic and Cenozoic dinoflagellates. In: Bolli, H.M., Saunders, J.B. \& Perch-Nielsen, K. (Eds), Plankton Stratigraphy. Cambridge University Press, Cambridge, 847-964.

Winchester-Seeto, T., Foster, C.B. \& O'Leary, T. 2000. The environmental response of Middle Ordovician large organic walled microfossils from the Goldwyer and Nita formations, Canning Basin, Australia. Review of Palaeobotany and Palynology, 113: 197-212.

Wing, S.L., Harrington, G.J., Smith, F.A., et al. 2005. Transient floral change and rapid global warming at the Paleocene-Eocene Boundary. Science, 310: 993-996.

Yule, B.L., Roberts, S.R. \& Marshall, J.E.A. 2000. The thermal evolution of sporpollenin. Organic Geochemistry, 31: 859-870.

\section{Nannofossil references}

Beaufort, L. \& Dollfus, D. 2004. Automatic recognition of coccoliths by dynamical neural networks. Marine Micropaleontology, 51 (1/2): $57-73$.

Beaufort, L., Lancelot, Y., Camberlin, P., et al. 1997. Insolation cycles as a major control equatorial Indian Ocean primary production. Science, 278: 1451-1454.

Bolli, H.M., Saunders, J.B. \& Perch-Nielsen, K. (Eds) 1985. Plankton stratigraphy. Cambridge University Press, Cambridge, 1006pp.

Bollmann, J. 1997. Morphology and biogeography of Gephyrocapsa coccoliths in Holocene sediments. Marine Micropaleontology, 29 (3/4): 319-350.

Bollmann, J., Henderiks, J. \& Brabec, B. 2002. Global calibration of Gephyrocapsa coccolith abundance in Holocene sediments for paleotemperature assessment. Paleoceanography, 17 (3): 1035. 
Bollmann, J., Quinn, P., Vela, M., et al. 2004. Automated particle analysis: calcareous microfossils. In: Francus, P. (Eds), Image Analysis, Sediments and Paleoenvironments. Kluwer Academic Publishing, Dordrecht, 229-252.

Bown, P.R. 1987. Taxonomy, evolution, and biostratigraphy of Late Triassic-Early Jurassic calcareous nannofossils. Special Papers in Palaeontology, 38: 1-118.

Bown, P.R. (Ed.) 1998. Calcareous nannofossil biostratigraphy. British Micropalaeontological Society Publication Series. Kluwer Academic, Dordrecht, 328pp.

Bralower, T.J., Arthur, M.A., Leckie, R.M., et al. 1994. Timing and Paleoceanography of Oceanic Dysoxia/Anoxia in the Late Barremian to Early Aptian (Early Cretaceous). Palaios, 9: 335-369.

Bralower, T.J., Leckie, R.M., Sliter, W.V. \& Thierstein, H.R. 1995. An integrated Cretaceous microfossil biostratigraphy. In: Berggren, W.A., Kent, D.V., Aubry, M.P. \& Hardenbol, J. (Eds), Geochronology, Time Scales and Global Stratigraphic Correlation. Society of Economic Palaeontologists and Mineralogists (SEPM), Special Publications, 54: 65-79.

Brassell, S.C., Eglington, G., Pflaumann, U. \& Sarnthein, M. 1986 Molecular stratigraphy: a new tool for climatic assessment. Nature, 320: $129-133$.

Burnett, J.A. 1998. Upper Cretaceous. In: Bown, P.R. (Ed.), Calcareous Nannofossil Biostratigraphy. British Micropalaeontological Society Publications Series. Chapman \& Hall, London, 132-199.

Dudley, W.C., Blackwelder, P.L., Brand, L.E. \& Duplessy, J.C. 1986. Stable isotopic composition of coccoliths. Marine Micropaleontology, 10 (1): $1-8$.

Erba, E. 1994. Nannofossils and superplumes: The early Aptian 'nannoconid crisis'. Paleoceanography, 9 (3): 483-501.

Gibbs, S.J., Bralower, T.J., Bown, P.R., Zachos, J.C. \& Bybell, L.M. 2006. Shelf and open-ocean calcareous phytoplankton assemblages across the Paleocene-Eocene Thermal Maximum: Implications for global productivity gradients. Geology, 34 (4): 233-236.

Holligan, P.M., Viollier, M., Harbour, D.S., Camus, P. \& Champagne-Philippe, M. 1983. Satellite and ship studies of coccolithophore production along a continental-shelf edge. Nature, 304: 339-342.

Minoletti, F., Rafelis, M.D., Renard, M., Gardin, S. \& Young, J.R. 2005. Changes in the pelagic fine fraction carbonate sedimentation during the Cretaceous-Paleocene transition: contribution of the separation technique to the study of Bidart section. Palaeogeography Palaeoclimatology Palaeoecology, 216 (1/2): 119-137.

Molfino, B. \& Mcintyre, A. 1990. Precessional forcing of nutricline dynamics in the equatorial Atlantic. Science, 249: 766-769.

Monechi, S. \& Thierstein, H.R. 1985. Late Cretaceous Eocene nannofossil and magnetostratigraphic correlations near Gubbio, Italy Marine Micropaleontology, 9 (5): 419-440.

Paasche, E. 2002. A review of the coccolithophorid Emiliania huxleyi (Prymnesiophyceae), with particular reference to growth, coccolith formation, and calcification-photosynthesis interactions. Phycologia, 40 (6): 503-529.

Paull, C.K. \& Thierstein, H.R. 1987. Stable isotopic fractionation among particles in Quaternary coccolith-sized deep-sea sediments. Paleoceanography, 2: 423-429.

Pospichal, J.J. 1994. Calcareous nannofossils at the K-T boundary, El Kef: No evidence for stepwise, gradual, or sequential extinctions. Geology, 22: 99-102.

Raffi, I., Backman, J., Fornaciari, E., et al. in press. A review of calcareous nannofossil astrobiochronology encompassing the past 25 million years. Quaternary Science Reviews.

Roth, P.H. \& Krumbach, K.R. 1986. Middle Cretaceous calcareous nannofossil biogeography and preservation in the Atlantic and Indian oceans - implications for paleoceanography. Marine Micropaleontology, 10 (1/3): 235-266.

Sáez, A.G., Probert, I., Young, J.R., Edvardsen, B., Wenche, E. \& Medlin, L.K. 2004. A review of the phylogeny of the Haptophyta. In: Thierstein, H.R. \& Young, J.R. (Eds), Coccolithophores - from molecular processes to global impact. Springer, Berlin, 251-270.

Thierstein, H.R. \& Young, J.R. (Eds) 2004. Coccolithophores - from molecular processes to global impact. Springer, Berlin, 570pp.
Varol, O. 1989. Eocene calcareous nannofossils from Sile (northwest Turkey). Revista Española de Micropaleontología, 21: 273-320.

Westbroek, P., Brown, C.W., Bleijswijk, J.V., et al. 1993. A model system approach to biological climate forcing. The example of Emiliania huxleyi. Global and Planetary Change, 8: 27-46.

Winter, A. \& Siesser, W.G. 1994. Coccolithophores. Cambridge University Press, Cambridge, 242pp.

Young, J.R., Didymus, J.M., Bown, P.R., Prins, B. \& Mann, S. 1992. Crystal assembly and phylogenetic evolution in heterococcoliths. Nature, 356: 516-518.

Ziveri, P., Thunell, R.C. \& Rio, D. 1995. Export production of coccolithophores in an upwelling region - results from San-Pedro Basin, Southern California Borderlands. Marine Micropaleontology, 24 (3/4): 335-358.

\section{Microvertebrate references}

Aldridge, R.J. \& Smith, M.P. 1993. Conodonta. In: Benton, M.J. (Ed.), The Fossil Record 2. Chapman \& Hall, London, 563-573.

Aldridge, R.J. \& Theron, J.N. 1993. Conodonts with preserved soft tissue from a new Ordovician Konservat-Lagerstätte. Journal of Micropalaeontology, 12: 113-119.

Aldridge, R.J., Briggs, D.E.G., Clarkson, E.N.K. \& Smith, M.P. 1986. The affinities of conodonts - new evidence from the Carboniferous of Edinburgh, Scotland. Lethaia, 19: 279-291.

Aldridge, R.J., Smith, M.P., Norby, R.D. \& Briggs, D.E.G. 1987. The architecture and function of Carboniferous polygnathacean conodont apparatuses. In: Aldridge, R.J. (Ed.), Palaeobiology of Conodonts. Ellis Horwood, Chichester, 63-76.

Aldridge, R.J., Briggs, D.E.G., Smith, M.P., Clarkson, E.N.K. \& Clark, N.D.L. 1993. The anatomy of conodonts. Philosophical Transactions of the Royal Society, London, Series B, 340: 405-421.

Armstrong, H.A. 1995. High-resolution biostratigraphy (conodonts and graptolites) of the Upper Ordovician and Lower Silurian- a chronometric framework in which to evaluate the causes of the mass extinction. Modern Geology, 20: 1-28.

Armstrong, H.A. 1999. Quantitative biostratigraphy. In: Harper, D.A.T. (Ed.), Numerical Techniques in Palaeontology. Chapman \& Hall, London, 181-226.

Armstrong, H.A. 2005. Modes of growth in the euconodont oral skeleton: implications for bias and completeness in the fossil record. In: Purnell, M.A. \& Donoghue, P.C.J. (Eds), Conodont Biology and Phylogeny - interpreting the fossil record. Special Papers in Palaeontology, 73: 27-38.

Armstrong, H.A. \& Owen, A.W. 2002. Euconodont diversity changes in a cooling and closing Iapetus Ocean. In: Crame, J.A. \& Owen, A.W. (Eds), Palaeobiogeography and Biodiversity Change: the Ordovician and Mesozoic-Cenozoic radiations. Geological Society, London, Special Publications, 194: 85-98.

Armstrong, H.A. \& Smith, C.J. 2001. Growth patterns in euconodont crown enamel: implications for life history and mode-of-life reconstruction in the earliest vertebrates. Proceedings of the Royal Society, London, series B, 268: 815-820.

Briggs, D.E.G., Clarkson, E.N.K. \& Aldridge, R.J. 1983. The conodont animal, Lethaia, 16: 1-14.

Caldwell, M.W. \& Wilson, M.V.H. 1995. Comparison of the body form and squamation of 'fork-tailed' agnathans with that of conventional thelodonts. Geobios Mémoire Spécial, 19: 23-29.

Donoghue, P.C.J. 1998. Growth and patterning in the conodont skeleton. Philosophical Transactions of the Royal Society, London, Series B, 353: 633-666.

Donoghue, P.C.J. \& Sansom, I.J. 2002. Origin and early evolution of vertebrate skeletonization. Microscopy Research and Technique, 59: 352-372.

Donoghue, P.C.J. \& Smith, M.P. 2001. The anatomy of Turinia pagei (Powrie), and the phylogenetic status of the Thelodonti. Transactions of the Geological Society of Edinburgh, 92: 15-37.

Donoghue, P.C.J., Forey, P.L. \& Aldridge, R.J. 2000. Conodont affinity and chordate phylogeny. Biological Reviews, 75: 191-251.

Gabbott, S.E., Aldridge, R.J. \& Theron, J.N. 1995. A giant conodont with preserved muscle tissue from the Upper Ordovician of South Africa. Nature, 374: 800-803. 
Holmden, C., Creaser, R.A., Muehlenbachs, K., Bergstrom, S.M. \& Leslie, S.A. 1996. Isotopic and elemental systematics of $\mathrm{Sr}$ and $\mathrm{Nd}$ in $454 \mathrm{Ma}$ biogenic apatites: Implications for paleoseawater studies. Earth and Planetary Science Letters, 142: 425-437.

Joachimski, M.M. \& Buggisch, W. 2002. Conodont apatite delta signatures indicate climatic cooling as a trigger of the Late Devonian $(\mathrm{F}-\mathrm{F})$ mass extinction. Geology, 30: 711-714.

Joachimski, M.M., von Bitter, P.H. \& Buggisch, W. 2006. Constraints on Pennsylvanian glacioeustatic sea-level changes using oxygen isotopes of conodont apatite. Geology, 34: 277-280.

Keto, L.S. \& Jacobsen, S.B. 1987. Nd and $\mathrm{Sr}$ isotopic variations of Early Palaeozoic oceans. Earth and Planetary Science Letters, 84: $7-41$.

Klapper, G. 1989. Frasnian species of the Late Devonian conodont Ancyrognathus. Journal of Paleontology, 64: 998-1025.

Kleffner, M.A. 1995. A conodont- and graptolite based Silurian chronostratigraphy. In: Mann, K.O., Lane, H.R. \& Scholle, P.A. (Eds), Graphic Correlation. Society for Sedimentary Geology (SEPM), Special Publication, 53: 159-176.

Mikulic, D.G., Briggs, D.E.G. \& Kluessendorf, J. 1985. A Silurian soft-bodied biota. Science, 228: 715-717.

Purnell, M.A.P. 1995. Microwear on conodont elements and macrophagy in the first vertebrates. Nature, 374: 798-800.

Purnell, M.A.P. \& Donoghue, P.C.J. 1998. Skeletal architecture, homologies and taphonomy of oarkodinid conodonts. Palaeontology, 41: $57-102$.

Sachs, H.M., Denkinger, M.L.B.C. \& Harris, A.G. 1980. Radiometric dating of sediments using fission tracks in conodonts. Nature, 288 : 359-361.

Sansom, I.J., Smith, M.P., Armstrong, H.A. \& Smith, M.M. 1992. Presence of the earliest vertebrate hard tissues in conodonts. Science, 256: $1308-1311$.

Sansom, I.J., Armstrong, H.A. \& Smith, M.P. 1994. The apparatus architecture of Panderodus and its implications for coniform conodont classification. Palaeontology, 37: 781-799.

Smith, M.P., Briggs, D.E.G. \& Aldridge, R.J. 1987. A conodont animal from the lower Silurian of Wisconsin, U. S. A., and the apparatus architecture of panderodontid conodonts. In: Aldridge, R.J. (Ed.), Palaeobiology of Conodonts. Ellis Horwood, Chichester, 91-104.

Smith, M.P., Donoghue, P.C.J. \& Sansom, I.J. 2002. The spatial and temporal diversification of Early Palaeozoic vertebrates. In: Crame, J.A. \& Owen, A.W. (Eds), Palaeobiogeography and Biodiversity Change: the Ordovician and Mesozoic-Cenozoic radiations. Geological Society, London, Special Publications, 194: 69-83.

Sweet, W.C. 1988. The Conodonta: morphology, taxonomy, paleoecology, and evolutionary history of a long-extinct animal phylum. Clarendon Press, Oxford, 212pp.

Sweet, W.C. 1989. A quantitative conodont biostratigraphy for the Lower Triassic. Senckenbergiana lethaea, 69: 253-273.

Sweet, W.C. 1995. Graphic assembly of a conodont-based composite standard for the Ordovician System of North America. In: Mann, K.O., Lane, H.R. \& Scholle, P.A. (Eds), Graphic Correlation. Society for Sedimentary Geology (SEPM) Special Publication, 53: 139-150.

Sweet, W.C. \& Donoghue, P.C.J. 2001. Conodonts: past, present and future. Journal of Paleontology, 75 (6): 1174-1184.

Turner, S. 1991. Monophyly and interrelationships of the Thelodonti. In: Chang, M.-m., Liu, Y.h. \& Zhang, G.-t. (Eds), Early Vertebrates and Related Problems of Evolutionary Biology. Science Press, Beijing, 87-119.

Ueki, S. \& Sano, Y. 2001. In situ microprobe Th-Pb dating of Silurian conodonts. Geochemical Journal, 35: 307-314.

Veizer, J., Fritz, P. \& Jones, B. 1986. Geochemistry of brachiopods: oxygen and carbon isotopic records of Paleozoic oceans. Geochimica et Cosmochimica Acta, 50: 1679-1696.

Veizer, J., Bracketing, P., Paulette, F., et al. 1997. Oxygen isotope evolution of Phanerozoic seawater. Palaeogeography Palaeoclimatology Palaeoecology, 132: 159-172.

Veizer, J., Ala, D., Azmy, K., et al. $1999 .{ }^{87} \mathrm{Sr} /{ }^{87} \mathrm{Sr}, \mathrm{d}^{87} \mathrm{C}$ and $\mathrm{d}^{87} \mathrm{O}$ evolution of Phanerozoic seawater. Chemical Geology, 161: 59-88.

Wilson, M.V.H. \& Caldwell, M.W. 1993. New Silurian and Devonian fork-tailed 'thelodonts' are jawless vertebrates with stomachs and deep bodies. Nature, 361: 442-444.
Wilson, M.V.H. \& Caldwell, M.W. 1998. The Furcacaudiformes: A new order of jawless vertebrates with thelodont scales, based on articulated Silurian and Devonian fossils from Northern Canada. Journal of Vertebrate Paleontology, 18: 10-29.

Wright, C.A. \& Barnes, C.R. 2002. Neodymium isotopic composition of Ordovician conodonts as a seawater proxy: Testing paleogeography. Geochemistry Geophysics Geosystems, 3 (2): doi. 10.1029/ 2001 GC000195.

Wright, J., Seymour, R.S. \& Shaw, H.F. 1984. REE and Nd isotopes in conodont apatite; variations with geological age and depositional environment. In: Clark, D.L. (Ed.), Conodont Biofacies and Provincialism. Geological Society of America, Special Paper, 196: 325-340.

Zhang, S., Aldridge, R.J. \& Donoghue, P.C.J. 1997. A Triassic conodont with periodic growth? Journal of Micropalaeontology, 16: 65-72.

\section{Radiolaria references}

Abelmann, A. \& Gowing, M.M. 1996. Horizontal and vertical distribution pattern of living radiolarians along a transect from the Southern Ocean to the South Atlantic subtropical region. Deep-Sea Research I, Oceanographic Research Papers, 43 (3): 361-382.

Abelmann, A., Brathauer, U., Gersonde, R., Sieger, R. \& Zielinski, U. 1999. Radiolarian-based transfer function for the estimation of sea surface temperatures in the Southern Ocean (Atlantic sector). Paleoceanography, 14 (3): 410-421

Amaral Zettler, L.A., Anderson, O.R. \& Caron, D.A. 1999. Towards a molecular phylogeny of colonial spumellarian radiolaria. Marine Micropaleontology, 36: 67-79.

Anderson, O.R. 1983. Radiolaria. Springer-Verlag, New York, 365pp.

Baumgartner, P.O., O'Dogherty, L., Gorican, S., et al. 1995. Middle Jurassic to Lower Cretaceous Radiolaria of Tethys: Occurrences, Systematics, Biochronology. Memoires de Geologie (Lausanne), 23: $1-1172$.

Blome, C.D. \& Reed, K.M. 1993. Acid processing of pre-Tertiary radiolarian cherts and its impact on faunal content and biozonal correlation. Geology, 21 (2): 177-180.

Boltovskoy, D. \& Riedel, W.R. 1987. Polycystine radiolaria of the California current region: Seasonal and geographic patterns. Marine Micropaleontology, 12: 65-104

Casey, R.E. 1987. Radiolaria. In: Broadhead, T.W. (Ed.), Fossil Prokaryotes and Protists; notes for a short course. Department of Geological Sciences, University of Tennessee, Knoxville, 213-247.

Caulet, J.P., Venec-Peyre, M.-T., Vergnaud-Grazzini, C. \& Nigrini, C. 1992. Variation of South Somalian upwelling during the last $160 \mathrm{ka}$ : radiolarian and foraminifera records in core MD 85674. In: Summerhayes, C.P., Prell, W.L. \& Emeis, K.C. (Eds), Upwelling Systems: evolution since the early Miocene. Geological Society, London, Special Publications, 64: 379-389.

Caulet, J.-P., Sanfilippo, A. \& Nigrini, C. 2006. 'Radworld', a taxonomic relational database for radiolarians. In: Lüer, V., Hollis, C., Campbell, H. \& Simes, J. (Eds), Inter Rad II and Triassic Stratigraphy Symposium. GNS Science Miscellaneous Series II. Lower Hutt, New Zealand, 47.

De Wever, P., Dumitrica, P., Caulet, J.P., Nigrini, C. \& Caridroit, M. 2001. Radiolarians in the Sedimentary Record. Gordon \& Breach, Amsterdam, 533pp.

Dolven, J. \& Skjerpen, H. 2000-2006. www.radiolaria.org.

Hollis, C.J. 1997. Cretaceous-Paleocene Radiolaria from eastern Marlborough, New Zealand. Institute of Geological and Nuclear Sciences, Monograph, 17: 1-152.

Kamata, Y., Matsuo, A., Takemura, A., et al. 2006. Primitive nassellarians from lower Triassic sequences in the Arrow Rocks, Waipapa Terrane, New Zealand. In: Lüer, V., Hollis, C., Campbell, H. \& Simes, J. (Eds), InterRad II and Triassic Stratigraphy Symposium. GNS Science Miscellaneous Series II. Lower Hutt, New Zealand, 75.

Kiessling, W. 1999. Late Jurassic radiolarians from the Antarctic Peninsula. Micropaleontology, 45 (suppl. 1): 1-96.

Lazarus, D. 1986. Tempo and mode of morphologic evolution near the origin of the radiolarian lineage Pterocanium prismatium. Paleobiology, 12 (2): 175-189. 
Lazarus, D. 1994. Neptune: a marine micropaleontology database Mathematical Geology, 26 (7): 817-832.

Lazarus, D.B. 2000. Ehrenberg, Haeckel and the problem of types: status report. In: Carter, E.S., Whalen, P., Noble, P.J. \& Crafford, A.E.J. (Eds), Ninth Meeting International Association of Radiolarian Paleontologists. Department of Geological Sciences, University of Nevada, Reno, 46.

Lazarus, D.B. 2005. A brief review of radiolarian research. Paläontologische Zeitschrift, 79 (1): 183-200.

Lazarus, D.B. in press. Radiolarians and Silicoflagellates. Encyclopedia of Quaternary Sciences. Elsevier, Amsterdam.

Lazarus, D. \& Caulet, J.P. 1994. Cenozoic Southern Ocean reconstructions from sedimentologic, radiolarian, and other microfossil data. In: Kennett, J.P. \& Warnke, D.A. (Eds), The Antarctic Paleonvironment: A Perspective on Global Change. Part 2. Antarctic Research Series: $145-174$

Lazarus, D., Bittniok, B., Diester-Haass, L., Meyers, P. \& Billups, K. 2006. Comparison of radiolarian and sedimentologic paleoproductivity proxies in the latest Miocene-Recent Benguela Upwelling System. Marine Micropaleontology, 60(4): 269-294.

Nigrini, C. \& Caulet, J.P. 1992. Late Neogene radiolarian assemblages characteristic of Indo-Pacific areas of upwelling. Micropaleontology, 38 (2): 139-164.

Pessagno, E.A. \& Blome, C.D. 1986. Faunal affinities and tectonogenesis of Mesozoic rocks in the Blue Mountains of eastern Oregon and western Idaho. In: Vallier, T.L. \& Brooks, H.C. (Eds), Geologic Implications of Paleozoic and Mesozoic Paleontology and Biostratigraphy, Blue Mountains Province, Oregon, Idaho and Washington. United States Geological Survey, Professional Paper, Washington D.C: 65-78.

Pisias, N.G., Roelofs, A. \& Weber, M. 1997. Radiolarian-based transfer functions for estimating mean surface ocean temperatures and seasonal range. Paleoceanography, 12 (3): 365-379.

Riedel, W.R. \& Sanfilippo, A. 1978. Stratigraphy and evolution of tropical Cenozoic radiolarians. Micropaleontology, 24 (1): 61-96.

Sanfilippo, A., Westberg-Smith, M.J. \& Riedel, W.R. 1985. Cenozoic Radiolaria. In: Bolli, H.M., Saunders, J.B. \& Perch-Nielsen, K. (Eds), Plankton Stratigraphy. Cambridge University Press, Cambridge, 631-712.

Sanfilippo, A., Nigrini, C.A., Caulet, J.P. \& Renz, G.W. 2000. RadRefs. a computerized radiolarian reference library. www. $\mathrm{mnhn} . \mathrm{fr} / \mathrm{mnhn} / \mathrm{geo} /$ radworld/radworldsite/research.html.

Suzuki, N., Aita, Y., Ogane, K., et al. 2006. Joint Haeckel and Ehrenberg project: a taxonomic re-examination of the Haeckel and Ehrenberg microfossil collections. In: Lüer, V., Hollis, C., Campbell, H. \& Simes, J. (Eds), InterRad II and Triassic Stratigraphy Symposium. GNS Science Miscellaneous Series II. Lower Hutt, New Zealand, 127.

Takahashi, K. 1991. Radiolaria: flux, ecology, and taxonomy in the Pacific and Atlantic. In: Honjo, S. (Ed.), Ocean Biocoenosis Series. Woods Hole Oceanographic Institution, Massachusetts, 303.

Welling, L.A. \& Pisias, N.G. 1998. Radiolarian fluxes, stocks, and population residence times in surface waters of the central equatoria Pacific. Deep-Sea Research Part I - Oceanographic Research Papers, 45 (4/5): 639-671.

Yamashita, H., Takahashi, K. \& Fujitani, N. 2002. Zonal and vertical distribution of radiolarians in the western and central Equatorial Pacific in January 1999. Deep-Sea Research Part II - Tropical Studies in Oceanography, 49: 2823-2862.

Yuasa, T., Takahashi, O., Dolven, J.K., et al. 2006. Phylogenetic position of the small solitary phaeodarians (Radiolaria) based on $18 \mathrm{~S}$ rDNA sequences by single cell PCR analysis. Marine Micropaleontology, 59 (2): 104-114.

\section{Diatom references}

Andersen, C., Koc, N., Jennings, A. \& Andrews, J.T. 2004. Nonuniform response of the major surface currents in the Nordic Seas to insolation forcing: implications for the Holocene climate variability. Paleoceanography, 19: PA2003, doi. 10.1029/2002PA000873.

Baldauf, J.G. 1984. Cenozoic diatom biostratigraphy and paleoceanography of the Rockall Plateau region, North Atlantic, Deep Sea Drilling Project Leg 81. Initial Reports of the DSDP, Leg 81: 439-478.
Baldauf, J.G. 1987. Diatom biostratigraphy of the middle- and highlatitude North Atlantic Ocean, Deep Sea Drilling Project Leg 94. Initial Reports of the DSDP, Leg 94 (2): 729-762.

Barber, K.E., Battarbee, R.W., Brooks, S.J., et al. 1999. Proxy records of climate change in the UK over the last two millennia: Documented change and sedimentary records from lakes and bogs. Journal of the Geological Society, London, 15: 369-380.

Barker, P.A., Street-Perrott, F.A., Leng, M.J., et al. 2001. A 14,000-year oxygen isotope record from diatom silica in two alpine lakes on $\mathrm{Mt}$ Kenya. Science, 291: 2307-2310.

Barron, J.A. 1980. Upper Pliocene and Quaternary diatom biostratigraphy of Deep Sea Drilling Project, Leg 54, tropical eastern Pacific. Initial Reports of the DSDP, Leg 54: 455-485.

Barron, J.A. 1981. Late Cenozoic diatom biostratigraphy and paleoceanography of the middle-latitude eastern North Pacific, Deep Sea Drilling Project, Leg 63. Initial Reports of the DSDP, Leg 63: 507-538.

Barron, J.A. 1985a. Late Eocene to Holocene diatom biostratigraphy of the equatorial Pacific Ocean, Deep Sea Drilling Project Leg 85. Initial Reports of the DSDP, Leg 85: 413-456.

Barron, J.A. 1985b. Diatom biostratigraphy of the CESAR 6 core, Alpha Ridge. Initial Geological Report on CESAR - the Canadian Expedition to study the Alpha Ridge. Geological Survey of Canada, 84-22: $137-143$.

Bianchi, C. \& Gersonde, R. 2004. Climate evolution at the last deglaciation: The role of the Southern Ocean. Earth and Planetary Science Letters, 228: 407-424.

Bigler, C. \& Hall, R. 2002. Diatoms as indicators of climatic and limnological change in Swedish Lapland: a 100-lake calibration set and its validation for paleoecological reconstructions. Journal of Paleolimnology, 27: 79-96.

Censarek, B. \& Gersonde, R. 2002. Miocene diatom biostratigraphy at ODP sites 689, 690, 1088, 1092 (Atlantic sector of the Southern Ocean). Marine Micropaleontology, 45 ((3-4)): 309-356.

Chalié, F. \& Gasse, F. 2002. Late Glacial-Holocene diatom record of water chemistry and lake level change from the tropical East African Rift Lake Abiyata (Ethiopia). Palaeogeography, Palaeoclimatology, Palaeoecology, 187: 259-283.

Chambers, P.M. 1996. Late Cretaceous and Palaeocene marine diatom floras. PhD thesis. University College London, London, 498pp.

Crosta, X., Pichon, J.-J. \& Burckle, L.H. 1998. Application of the modern analog technique to marine Antarctic diatoms: reconstruction of maximum sea-ice extent at the Last Glacial Maximum. Paleoceanography, 13: 284-297.

Cunningham, W.L., Leventer, A., Andrews, J.T., Jennings, A.E. \& Licht, K.J. 1999. Late Pleistocene-Holocene marine conditions in the Ross Sea, Antarctica: Evidence from the diatom record. Holocene, 9: 129-139.

De La Rocha, C.L. 2006. Opal based isotopic proxies of paleoenvironmental conditions. Global Biogeochemical Cycles, 20: doi. 10.1029/2005GB002664.

De La Rocha, C.L., Brzezinski, M.A., De Niro, M.J. \& Shemesh, A. 1998. Silicon-isotope composition of diatoms as an indicator of past oceanic change. Nature, 395: 680-683.

Dell'Anglese, D.J. \& Clark, D.L. 1994. Siliceous microfossils from the warm Late Cretaceous and early Cenozoic Arctic Ocean. Journal of Paleontology, 68: 31-47.

Domack, E., Duran, D., Leventer, A., et al. 2005. Stability of the Larsen $B$ ice shelf on the Antarctic Peninsula during the Holocene epoch. Nature, 436: 681-685.

Fallu, M.-A., Allaire, N. \& Pienitz, R. 2002. Distribution of freshwater diatoms in 64 Labrador (Canada) lakes: Species-environment relationships along latitudinal gradients and reconstruction models for water colour and alkalinity. Canadian Journal of Fisheries and Aquatic Science, 59: 329-349.

Fenner, J. 1984. Middle Eocene to Oligocene planktonic diatom stratigraphy from Deep Sea Drilling Project Sites in the South Atlantic, equatorial Pacific, and Indian Oceans. Initial Reports of the DSDP, Leg 75 (2): 1245-1271

Gasse, F., Juggins, S. \& Khelifa, L.B. 1995. Diatom-based transferfunctions for inferring past hydrochemical characteristics of African lakes. Palaeogeography, Palaeoclimatology, Palaeoecology, 117: $31-54$. 


\section{F. J. Gregory et al.}

Gersonde, R. \& Burckle, L.H. 1990. Neogene diatom biostratigraphy of ODP Leg 113, Weddell Sea (Antarctic Ocean). Proceedings of the ODP Scientific Results, Leg 13: 761-789.

Gersonde, R. \& Harwood, D.M. 1990. Lower Cretaceous diatoms from ODP Leg 113 site 693 (Weddell Sea) Part 1: Vegetative cells. Proceedings of the ODP Scientific Results, 113: 365-402.

Gersonde, R., Crosta, X., Abelmann, A. \& Armand, L. 2005. Seasurface temperature and sea ice distribution of the Southern Ocean at the EPILOG Last Glacial Maximum - A circum-Antarctic view based on siliceous microfossil records. Quaternary Science Reviews, 24 869-896.

Gladenkov, A.Y. \& Barron, J.A. 1995. Oligocene and early middle Miocene diatom biostratigraphy of Hole 884B. Proceedings of the ODP Scientific Results, 145: 21-41.

Harwood, D.M. 1988. Upper Cretaceous and lower Paleocene diatom and silicoflagellate biostratigraphy of Seymour Island, eastern Antarctic Peninsula. Geological Society of America, Memoir, 16: $55-129$.

Harwood, D.M. \& Gersonde, R. 1990. Lower Cretaceous diatoms from ODP Leg 113 Site 693 (Weddell Sea). Part 2: resting spores, chrysophycean cysts, an endoskeletal dinoflagellate, and notes on the origin of diatoms. Proceedings of the ODP Scientific Results, 113: 403-425.

Harwood, D.M. \& Maruyama, T. 1992. Middle Eocene to Pleistocene diatom biostratigraphy of ODP Leg 120, Kerguelen Plateau. Proceedings of the ODP Scientific Results, 120: 683-733.

Heiri, O. \& Lotter, A. 2005. Holocene and Late glacial summer temperature reconstruction in the Swiss Alps based on fossil assemblages of aquatic organisms: A review. Boreas, 34: 506-516.

Koc, N., Hodell, D.A., Kleiven, H. \& Labeyrie, L. 1999. Highresolution Pleistocene diatom biostratigraphy of Site 983 and correlations with isotope stratigraphy. Proceedings of the ODP Scientific Results, 162: 51-62.

Koizumi, I., Irino, T. \& Oba, T. 2004. Paleoceanography during the last 150 kyr off central Japan based on diatom floras. Marine Micropaleontology, 53: 293-365.

Kooistra, W.H.C.F., Gersonde, R., Medlin, L.K. \& Mann, D.G. in press. Evolution of planktonic diatoms: The origin and evolution of the diatoms: their adaptation to a planktonic existence. In: Falkowski, P.G. \& Knoll, A.H. (Eds), The Evolution of Aquatic Photoautotrophs. Academic Press, New York.

Lange, C.B., Berger, W.H., Lin, H.-L. \& Wefer, G. 1999. The early Matuyama Diatom Maximum off SW Africa, Benguela Current System (ODP Leg 175). Marine Geology, 161: 93-114.

Maruyama, T. 2000. Middle Miocene to Pleistocene diatom stratigraphy of Leg 167. Proceedings of the ODP Scientific Results, 167: 63-110.

Pienitz, R., Smol, J.P. \& Briks, H.J.B. 1995. Assessment of freshwater diatoms as quantitative indicators of past climatic change in the Yukon and Northwest Territories, Canada. Journal of Paleolimnology, 13: 21-49.

Rietti-Shati, M., Shemesh, A. \& Karlen, W. 1998. A 3000-year climatic record from biogenic silica oxygen isotopes in an equatorial highaltitude lake. Science, 281: 980-982.

Schneider-Mor, A., Yam, R., Bianchi, C., et al. 2005. Diatom stable isotopes, sea ice presence and sea surface temperature records of the past $640 \mathrm{ka}$ in the Atlantic sector of the Southern Ocean. Geophysical Research Letters, 32: 1-4.

Shemesh, A., Burckle, L.H. \& Hays, J.D. 1994. Meltwater input to the Southern Ocean during the last glacial maximum. Science, 266: $1542-1544$.

Sigman, D.M., Altabet, M.A., Francois, R., et al. 1999. The isotopic composition of diatom-bound nitrogen in Southern Ocean sediments. Paleoceanography, 14: 118-134.

Sims, P.A., Mann, D.G. \& Medlin, L.K. 2006. Evolution of the diatoms: insights from fossil, biological and molecular data. Phycologia, 45: 361-402.

Tapia, P.M. \& Harwood, D.M. 2002. Upper Cretaceous diatom biostratigraphy of the Arctic Archipelago and northern continental margin, Canada. Micropaleontology, 48: 303-342.

Zielinski, U. \& Gersonde, R. 2002. Plio-Pleistocene diatom biostratigraphy from ODP Leg 177, Atlantic sector of the Southern Ocean. Marine Micropaleontology, 45: 225-268.

Zielinski, U., Gersonde, R., Sieger, R. \& Fütterer, D.K. 1998. Quaternary surface water temperature estimations - calibration of diatom transfer functions for the Southern Ocean. Paleoceanography, 13: $365-383$. 